KS. SZYMON FEDOROWICZ* - KRAKÓW

\title{
ŚREDNIOWIECZNE LEKCJONARZE W ZBIORACH WAWELSKICH
}

W zbiorach Archiwum i Biblioteki Krakowskiej Kapituły Katedralnej przechowywane są trzy średniowieczne lekcjonarze, zawierające łacińskie teksty czytań, które przeznaczone były do odczytywania lub odśpiewywania podczas liturgii mszalnej. I chociaż z natury rzeczy są do siebie bardzo podobne w treści, to jednak różnią się między sobą cechami indywidualnymi, zrozumiałymi w odniesieniu do niepowtarzalnych przecież kodeksów rękopiśmiennych. Charakterystykę i odmienności wszystkich trzech ksiąg przedstawimy osobno, natomiast ich zawartość merytoryczną w jednym ogólnym zestawieniu.

\section{Lectionarium - KP 201}

Kodeks nie posiada strony tytułowej. Liczy w całości 142 karty w 18 poszytach (składkach) z częściowo podwójną foliacją wykonaną współcześnie w górnym i dolnym rogu prawej strony. Karta pierwsza, czwarta i ostatnia zostały doklejone do swoich składek, natomiast karty piąta i szósta, chociaż ze sobą również sklejone, to jednak od całości składki są oderwane ${ }^{2}$. W takiej sytuacji pierwsza składka posiada tylko 1 nienaruszony arkusz. Druga składka zaczyna się zatem od karty siódmej i ma 4 arkusze (quaternion), czyli 8 kart, tak jak pozostałe poszyty. Wyjątkiem jest składka 10, która liczy 7 kart (wycięto jedną kartę pomiędzy k. 71 i 72) oraz składki 3, 4 i 9, które posiadały po 5 arkuszy (quinternion), ale wycięto z nich po dwie karty (pomiędzy 16 i 17, 21 i 22, 25 i 26, 28 i 29, 63 i 64, 68 i 69).

${ }^{*}$ Ks. Szymon Fedorowicz - mg historii, dr liturgiki.

${ }^{1}$ I. Polkowski, Katalog rękopisów kapitulnych katedry krakowskiej, Kraków 1884, s. 38-39; J. W. Boguniowski, Rozwój historyczny ksiag liturgii rzymskiej do Soboru Trydenckiego i ich recepcja w Polsce, Kraków 2001, s. 95-97; Źródla kultury duchowej Krakowa, Archiwum i Biblioteka Krakowskiej Kapituły Katedralnej, Kraków 2007, s. 146-149; A. Vetulani, Krakowska biblioteka katedralna w świetle swego inwentarza z r. 1110, „Slavia Antiqua”, 4 (1953) s. 163-192.

${ }^{2}$ Jeżeli każda składka liczyła po 8 kart, to jeden jedyny raz występujący w tym kodeksie kustosz (numer składki) „III” w stopce k. 6v świadczyłby o braku aż 18 początkowych kart. 
Karta 107 jest częściowo doklejona do składki, a częściowo doszyta. Uwagę przykuwa natomiast składka 17, w której arkusze zostały złożone w złej kolejności.

Aktualna oprawa wykonana została w XIX wieku, o czym świadczy użyty do tego materiał. Stanowią ją dwie cienkie deseczki (155x245 mm) obleczone bordowym aksamitem. Na zniszczonym i pozbawionym tejże aksamitnej osłony grzbiecie łatwo dostrzega się brzegi złożonych poszytów i wiążący ja sznurek. Karty kodeksu są nieznacznie mniejsze od samej oprawy $(155 \times 240 \mathrm{~mm})$. Pergamin wykorzystany do ich wykonania jest niejednolity. Są karty bardzo cienkie i giętkie, ale też stosunkowo grube i sztywne. Materiał nie został dobrze wyprawiony. Świadczą o tym często występujące pofałdowania, pęknięcia i przecięcia, zszycia z zachowanymi nićmi, liczne dziury i ubytki, które częściowo uzupełniono białym papierem, odbijającym się rażąco od żółto-szarej barwy pergaminu. W nielicznych miejscach można dostrzec ślady rozmazania inkaustu spowodowane zachlapaniem woda. Niektóre karty pozostają węższe albo krótsze, mimo dokonanego później przez introligatora niezbyt szczęśliwego przycięcia całości. Niewielkie otwory, będące dziełem pewnego gatunku robaczków, dopełniają obrazu księgi brudnej i zniszczonej.

Zapis tekstu na stronie tworzy regularną kolumnę $(100 \times 170 \mathrm{~mm})$, której ramy wyznaczają delikatne linie. Takie same poziome linie wyznaczają miejsce poszczególnym wierszom, które czasem wychodzą poza pionową linię ograniczającą kolumnę od prawej strony, a których na każdej stronie przewidziano 17 (tylko na stronie 86v jest 18 wiersz umieszczony w nagłówku). Odstęp pomiędzy tymi liniami wynosi $10 \mathrm{~mm}$, co umożliwiło wpisanie liter o wysokości $5 \mathrm{~mm}$ (dużych $-6 / 7 \mathrm{~mm}$ ), natomiast tam, gdzie w jednej linii umieszczono dwa wiersze tekstu litery są drobne i wynoszą $2 / 4 \mathrm{~mm}$. Ma to miejsce na stronach, gdzie znajdują się lekcje dla mszy o świętych, ale w odniesieniu do znacznej większości tych tylko obchodów, dla których przeznaczono czytanie z tekstów wspólnych. W takich przypadkach podano tylko imię świętego (rubrem) i incipit przewidzianej lekcji (czarnym inkaustem) $)^{3}$. Rękopis sporządzono dwunastowieczną minuskułą romańską, zapowiadającą już nieśmiało pismo gotyckie ${ }^{4}$. Na kartach 78 i 79 pismo to jest nieco odmienne i być może wskazuje na rękę innego pisarza. Wykorzystano czarny inkaust, a dla wyróżnienia rubryk cynober.

Lekcjonarz posiada ozdobne inicjały, ale niektóre spośród nich zwracaja szczególniejszą uwagę. Tych w całej księdze jest 18, a wyróżniają się od pozostałych wzbogaceniem o oryginalne dodatkowe elementy. Jedne zwieńczone są główkami ptaków ${ }^{5}$, inne ozdobione głowami ludzkimi ${ }^{6}$, a jeszcze inne - i tych jest najwięcej - łbami zwierząt drapieżnych ${ }^{7}$. Największy i najbardziej wyekspono-

${ }^{3}$ Karty $117 \mathrm{v}, 118 \mathrm{r}, \mathrm{v}, 121 \mathrm{v}, 123 \mathrm{r}, \mathrm{v}, 124 \mathrm{r}, \mathrm{v}, 125 \mathrm{v}, 126 \mathrm{r}, 127 \mathrm{r}, 128 \mathrm{r}, 129 \mathrm{v}$.

${ }^{4}$ W. Semkowicz, Paleografia łacińska, Kraków 1951, s. 283-288.

${ }^{5}$ Karty $15 \mathrm{r}, 135 \mathrm{v}$.

${ }^{6}$ Karty $71 \mathrm{v}, 120 \mathrm{r}, 124 \mathrm{v}, 128 \mathrm{v}$.

${ }^{7}$ Karty 18r, 30r, 38v, 41v, 46r, 57r, 73v, 76v, 123v, 126v (w tym inicjale umieszczono dwa tby), 139r. Interesującą analizę artystyczną podaje M. Krasnodębska-D'Aughton: „W kodeksie występują zarówno inicjały zdobione jedynie prostym ornamentem, jak i zawierające motywy antropo- i zoomorficzne. Inicjał B (Beatus) otwierający teksty wspólne o świętych (k. 131v) wykorzystuje mo- 
wany romański inicjał $\mathrm{F}$ (Fratres; pozostałe litery tego wyrazu są duże i podcieniowane czerwoną farba, $\mathrm{k}$. 56v), z charakterystycznymi dla sztuki tego okresu splotami, rozciaga się na długość 8 linii. Jest to czerwono-zielona kompozycja z nieznacznym dodatkiem jasno brązowego koloru. Wszystkie inicjały ozdobne wykonano przy użyciu tych właśnie kolorów, chociaż nie zawsze wykorzystywano je w pełnym zestawieniu. Najczęściej są dwukolorowe, ale nie brakuje też jednokolorowych i te nie posiadają już żadnych ozdób. Ich wielkość jest zróżnicowana - od wysokości nie przekraczającej dwóch linii, aż po wydłużenie sięgające dwunastu linii. Poza tymi inicjałami są jeszcze inne, małe, nie rzucające się w oczy i nie przekraczające wysokości 1 linii, zawsze koloru czerwonego. One rozpoczynają właściwy tekst lekcji, pozostawiając zdobienia dla zwrotów wprowadzających: „Fratres”, „In diebus illis”, „Hec dicit Dominus”, „Karissimi”. Ponadto podcieniowano czerwoną farbą występujące w tekście duże litery.

Rubryki w lekcjonarzu podają dość wyczerpująco informacje o dniu liturgicznego obchodu oraz o tytule biblijnej księgi, z której zaczerpnięto daną lekcję. Nierzadko pojawiają się też zwroty „,in modum lectionis lege" $\mathrm{i}$, ,in modum epistole lege", ale częściej na marginesie, w nagłówkach i na stopkach strony, niż we właściwym im miejscu; na karcie 79r zaznaczono nawet „,in tonis episto[le]”. Te informacje wskazywałyby na tak zwany tonus recitativus, stosowany $\mathrm{w}$ liturgii słowa ${ }^{9}$. Są również informacje typu ,sine titulo” lub wyraźniej „lectio absque titulo" (68r). Bywają instrukcje szczególniejsze: „post orationem sequitur hec lectio" (54r), „Item post orationem sequitur lectio hec” (55v), czy dopisana odręcznie na marginesie „Epistola qui legitur tempore paschali sabbatis diebus de domina Reversi sunt apostoli, require in fine libri in aliis folis" (130r). Również na marginesach zaznaczono, ale już czarnym inkaustem, incipity introitów, to znaczy antyfon na wejście dla wszystkich niedziel oraz dni powszednich Wielkiego Postu i dni w oktawach Wielkanocy i Zesłania Ducha Świętego. W nagłówkach kilku ostatnich kart zaznaczono czerwoną farbą i pismem głównie rozstrzelonym tytuły tych części commune, do których należą zapisane na nich lekcje: „In vigilia apo-

tywy akantu i wstęg zdobionych drogimi kamieniami. Inicjał I (In diebus, k. 128v) ma kształt pięknie wykonanej piórkiem hybrydy: składa się z ptasiego torsu zwieńczonego ludzką głową ujętą w lekkim skrócie. Inne I (In diebus, k. 135v) jest ozdobione ptasią głową i korpusem z ogonem ryby. Rękopis zawiera wiele inicjałów zdobionych motywem głowy lwa. Wszystkie inicjały wykonane są $\mathrm{z}$ wielką biegłością i precyzją. Liściaste zwoje i fantastyczne bestie, dominujące w inicjałach, wykazują wpływy północnej Francji i krainy Renu. Jest możliwe, że rękopis został wykonany i ozdobiony w Krakowie przez artystę korzystającego z różnorodnych wzorów”, Źródta kultury duchowej Krakowa,s. 146.

${ }^{8} \mathrm{Na}$ k. $17 \mathrm{r}$ ten zwrot otrzymał przedłużenie w słowach: „et alias similiter leguntur”.

${ }^{9}$ Zob. Sebastian z Felsztyna, Modus regulariter accentuandi lectiones matutinales, prophetias necnon epistolas et euangelia, Cracoviae 1518, gdzie autor dokładnie, z wieloma przykładami, opisuje w kolejnych rozdziałach: 1 - „de pronuntiatione lectionum”, 2 - „epistolarum”, 3 - „euangeliorum", sposoby odczytywania wymienionych rodzajów tekstów. Ponadto podaje przykłady tonów tytułów i zakończeń listów i ewangelii. Por. I. Polkowski, Katalog rękopisów, dz. cyt., s. 39: „Książka ta widocznie przeznaczona dla subdiakona do śpiewania lekcji w czasie mszy św., co ztąd się pokazuje, że nad wyrazami jest mnóstwo znaczków zastępujących solfy czyli nuty”. 
stoli”, „De apostolis”, „De ewangelistis”, „De martiribus” (131v, 133r-138r, 139v$142 \mathrm{v})$.

W kodeksie znajdują się różnego rodzaju błędy - choć jest ich stosunkowo niewiele - które zostały poprawione: uzupełnienia, najczęściej nad tekstem bieżącym, ale też na marginesie $(1 \mathrm{v}-$ illum, $4 \mathrm{v}$ - manibus, $5 \mathrm{v}$ - nobis, $19 \mathrm{v}-$ tias nad skróconym prophetas, $20 \mathrm{r}$ - vas, $27 \mathrm{r}$ - dominus, $51 \mathrm{r}$ - non, $52 \mathrm{r}-$ deus, $55 \mathrm{r}$ - bi nad u-, $78 \mathrm{r}$ - alterutrum, $83 \mathrm{r}$ - suam, supra, $84 \mathrm{v}-$ dei, $85 \mathrm{v}-$ vite, $98 \mathrm{v}-$ vos, $100 \mathrm{v}$ - dopisano obok pominięty fragment z księgi Ezdrasza: „Flebat enim omnis populus cum audiret verba legis", $112 \mathrm{v}$ - quas, $114 \mathrm{r}$ - rubryka: Thome martiri, incipit: „Omnis pontifex”, $117 \mathrm{v}$ - przy s. Marci Require in epistola „Vidi et ecce” de ewangelistis, $123 \mathrm{v}$ - przy s. Iacobi rubryka: Vigilia apostoli, incipit: „Beatus homo qui inve[nit]”, 125v - przy In exaltatione s. crucis: vel „Confido de vobis” require in inventione eiusdem, $136 \mathrm{v}-$ nec revertebantur, $141 \mathrm{r}$ - et in beneplacite), skreślenia (45r - czerwoną kreską iudei, 96r - labora, ponad napisano laborant), poprawki (6r i $7 \mathrm{v}$ - dwukrotnie nad błędnym ad romanos wpisano ad corinthios, $78 \mathrm{r}$ - nad intelligimus napisano cognoscimus, 90r - obok błędnego ad colosenses zaznaczono 1. ad corinthios XII, 136r - pod eorum zaznaczono vel animalium, $142 \mathrm{v}$ - nad et dopisano ut), inne (6v - nad zamazanym tytułem księgi wpisano Ep ad hebreos, $17 \mathrm{r}$ - zamazane i nieczytelne prave, $26 \mathrm{r}$ - nad wymazanym słowem napisano irrugiit, $125 \mathrm{v}$ - wymazano tekst $\mathrm{w}$ dwóch liniach i pozostawiono puste miejsce). Ponadto, poza wyżej wskazanymi, pomylono dwa razy nazwę księgi w rubryce, nie dokonując później żadnej korekty $(18 \mathrm{v}, 107 \mathrm{v})$, jeden raz pomylono dzień tygodnia $(110 \mathrm{v})$, oraz czterokrotnie dopisywano wskazówkę: „Require”, odsyłając do tekstu umieszczonego w innym miejscu lekcjonarza $(65 \mathrm{v}, 67 \mathrm{r}, 69 \mathrm{v})$.

Uszkodzenie kodeksu jest jeszcze poważniejsze, niż tylko nieobecność strony tytułowej, bowiem brakuje w nim kilkunastu kart początkowych, a także kilkunastu końcowych. Pierwsza strona zaczyna się od słów: ,et reges in splendore ortus tui...” (Is $60,3 \mathrm{~b} . .$. ), będących fragmentem lekcji na Epifanię, której początek znajdował się na poprzedzającej, nie zachowanej karcie. Druga strona tej samej karty kończy się słowami: „det vobis pacem” (1Th 3, 16a), na których urywa się tekst lekcji z piątku po Niedzieli w oktawie Epifanii. Również karta następna wskazuje na ubytki w księdze (w tym miejscu brakuje jednej karty), bowiem rozpoczyna się słowami: „[preveni]entes. Sollicitudine non pigri...” (Rm 12, 11), a pierwszy wyraz w wyniku podzielenia posiada tylko końcówkę. Jest to z kolei fragment lekcji z 2 Niedzieli po Epifanii. Podobna sytuacja jest na końcu księgi. Tekst ciagły urywa się na przedostatniej karcie (141) na słowach: „qui amicti sunt” (Apc 7, 13), które są początkiem lekcji znajdującej się w zbiorze tekstów wspólnych o męczennikach, natomiast karta następna (142) rozpoczyna się słowami: „probatur Christo igitur passo in carne...." $(1 \mathrm{Pt} 4,1) \mathrm{z}$ końcowej części innej lekcji również o męczennikach. Między tymi kartami także brakuje jednej karty. Na ostatniej stronie (142v) znajduje się niedokończona lekcja z tego samego zbioru, uszkodzona tylko nieznacznie: „nos patimur et spes nostra” $(2$ Cor 1,7$)$, co również świadczy o braku ostatnich kart.

Lekcjonarz nie posiada kalendarza liturgicznego. Zawiera (pomijając wspomniane wcześniej brakujące karty) lekcje czytań mszalnych na cały rok. Porządek 
jest następujący: najpierw temporale $-1 \mathrm{r}-113 \mathrm{v}^{10}$, następnie sanctorale od $114 \mathrm{r}^{11}$. Karty od 127 do 132 nie są ułożone po kolei. Nowożytny introligator - zapewne przez pomyłkę - czwarty (środkowy) arkusz tej składki złożył jako drugi i w związku z tym karta czwarta stała się drugą (127), a karta piąta siódmą (132), a powinny być - odpowiednio - 129 i 130. Ten błąd zakłócił całą foliację tej składki i stąd nie sposób wskazać precyzyjnie miejsca końcowej części sanctorale oraz następującego zaraz po niej zbioru lekcji dla mszy wotywnych i początkowej części commune, która kończy się na karcie $142^{12}$. Na stronach 130r-131v znajdują się lekcje na obchód Dedicatio ecclesie. Osobliwością manuskryptu jest parokrotne występowanie incipitów tractus wykonywanych zaraz po odczytaniu lekcji $(51 \mathrm{r}, 55 \mathrm{r}, \mathrm{v})$.

Autor rękopisu pozostaje nieznany. Natomiast czas jego powstania można określić w dużym przybliżeniu ${ }^{13}$. Pismo wskazuje na drugą połowę wieku XII, ale informacje zawarte w sanctorale umożliwiają ściślejsze datowanie. Umieszczono w nim obchód św. Wacława (Wencezlai, k. 126r), co wobec braku innych patronów czeskich pozwala wskazać na Kraków jako miejsce jego powstania. Otóż nie ma w kodeksie żadnej wzmianki o św. Florianie, który stał się głównym patronem tego miasto po sprowadzeniu jego relikwii w 1184 roku, zaś obchód św. Tomasza Becketa, kanonizowanego w 1173 roku, starannie dopisano tą samą ręką na marginesie. Można zatem przypuszczać, że lekcjonarz ów powstał niedługo przed tą ostatnią datą albo nawet dokładnie w tym czasie.

\section{Lectionarium - KP $21^{14}$}

Lekcjonarz ten - tak samo jak poprzedni - nie posiada strony tytułowej. Pierwszą kartę rozpoczynają słowa lekcji na 1 Niedzielę Adwentu: „Fratres. Scientes quia hora iam est". Kodeks zachował się w nie najlepszym stanie. Oprawiono go w XIX wieku wyposażając w dwie tekturowe okładki $(155 \times 245 \mathrm{~mm})$ i pokrywając jego grzbiet, pochodzącym z uszkodzonego kodeksu KP 20, szerokim paskiem bordowego aksamitu, na którym wytłoczono i pozłocono - słabo już widoczny - napis „Lectionarium”. Niezbyt udana introligatorska praca pozostawiła jeszcze jeden ślad: przycięto, mianowicie, wszystkie karty, nie naruszając

\footnotetext{
${ }^{10} \mathrm{Na}$ tej stronie (113v) znajdują się tylko trzy linie tekstu lekcji, pozostała przestrzeń pozostaje pusta.

${ }^{11}$ Tytuł: „Incipiunt epistole de sanctis per circulum anni” został umieszczony w ostatniej linii k. $113 \mathrm{v}$.

${ }^{12} \mathrm{Na}$ karcie 131v: „Incipiunt epistole communes de sanctis”.

${ }^{13}$ I. Polkowski twierdzi, że ów lekcjonarz ,jest w spisie kodeksów z r. 1110" (Katalog rękopisów, s. 38). Ale, jak przekonuje A. Vetulani: „nie można zaliczać do starego zasobu biblioteki katedralnej dzisiejszego ms. 20 biblioteki kapitulnej, jak pragnął tego ks. Polkowski, dopatrując się w nim jednego $\mathrm{z}$ pięciu lekcjonarzy wymienionych $\mathrm{w}$ inwentarzu $\mathrm{z}$ r. 1110. Lekcjonarz zawarty $\mathrm{w}$ tym rękopisie (...) pochodzi - jak wskazuje na to charakter pisma - najwcześniej z początku wieku XIII. (...) najprawdopodobniej sporządzono go w Krakowie" (Krakowska biblioteka katedralna, s. 180$-181)$.

${ }^{14}$ Polkowski, Katalog rękopisów, s. 39; Boguniowski, Rozwój historyczny ksiag, s. 97-98.
} 
jednak w niczym powierzchni zapisanej tekstem zasadniczym. O nieznacznym okrojeniu kart zaświadczają drobne i mało istotne inskrypcje, które znajdują się na szerokim marginesie. Karty są pergaminowe $(145 \times 235 \mathrm{~mm})$ i jest ich 48 . Dwie ostatnie są w stanie poważnego uszkodzenia - karta 47 nie posiada dolnej połowy, zaś 48 jest zaledwie ćwiercią (górną) całości. Razem tworzą pięć składek (poszytów): dwie pierwsze liczą po 5 arkuszy, czyli po 10 kart, trzecia i czwarta posiadają po 6 arkuszy (sexternion), lecz z powodu usunięcia w każdej z nich po dwie karty (pomiędzy 24 i 25, 25 i 26 oraz 30 i 31, 35 i 36) ostatecznie również mają ich po 10; składka piąta ma 3 arkusze (ternion - 6 kart), a dwie ostatnie wybrakowane karty zostały tylko dołączone do pozostałych. Paginacja jest współczesna, niepełna, wykonana bądź ołówkiem, bądź długopisem(!). Użyty pergamin jest dobrze wyprawiony, cienki, z widocznymi pofałdowaniami, pęknięciami, otworami i zszyciami z zachowanymi nićmi.

Kodeks jest liniowany. Jedna kolumna tekstu na stronie liczy 17 wierszy (k. 1-20 i 41-46), co daje jej wymiary $173 \times 95 \mathrm{~mm}$ lub 16 wierszy (k. 21-40) i wtedy osiagga ona rozmiar $168 \times 100 \mathrm{~mm}$. Niektóre karty mają nietypową liczbę linii (k. $28 v$ i 29 r - 14, k. 29v i 30r-15). Zaznaczyć trzeba, że wielkość poszczególnych kolumn o tej samej liczbie wierszy nie jest identyczna, ale różnice są nieznaczne. W linie szerokości $10 \mathrm{~mm}$ wpisano tekst, którego litery krótkie mają wysokość 4-5 $\mathrm{mm}$, długie $-7 \mathrm{~mm}$. Samo pismo to starannie wykonana gotycka tekstura, ale z pewnymi cechami bastardy ${ }^{15}$; od karty 41-46 jest wyraźnie odmienne, sporządzone inną ręką. Wykorzystano czarny inkaust, który miejscami jest trochę wyblakły. Rubryki zapisano kolorem czerwonym - rubrem. Lectionarium nie posiada żadnych zdobień. Tylko pierwszy inicjał „F” jest znacznie większy od pozostałych, wydłużony na dwanaście linii, i dwukolorowy. Takie wyjątkowe przeciągnięcie inicjału poza własną linię napotkamy jeszcze tylko jeden raz (też 12 linii, $\mathrm{k}$. $15 \mathrm{v}$ ), natomiast pozostałe w większości zajmują wysokość 2 linii, albo 3, zwłaszcza, gdy są to litery długie. Zdarzają się także inicjały małe na pełną wysokość tylko 1 linii. Zapisano je w kolorach czerwonym i niebieskim, na przemiennie. Pierwsze litery zdań lub wierszy w tekstach lekcji podcieniowano czerwienią. Ówczesna oszczędność materiału pisarskiego znajduje odzwierciedlenie w układzie stron, na których nie ma - tak samo, jak w poprzednim lekcjonarzu - żadnych odstępów, akapitów, przerw - wszystko pisane jest w jednym nieprzerwanym ciągu, zarówno tekst podstawowy, jak i towarzyszące mu rubryki.

Rubryki są bardzo skąpe - głównie są to tytuły lekcji i rzadziej nazwy dni liturgicznych ${ }^{16}$, ale notowane bardzo niekonsekwentnie i wykazujące szereg braków. Jeden z takich zapisów ogranicza się do zwięzłego: „sine titulo” (12v). Na marginesach, obok prawie każdej takiej rubryki, drobnym odręcznym pismem zanotowano w skrócie tę samą lub uzupełniającą informację. W piątej składce natomiast rubryk nie sporządzono prawie wcale, pozostawiając puste miejsca, przeznaczone na ich wpisanie, czego już nie uczyniono. Charakterystyczne są tutaj skróty „-mi”, „-me”, którym brakuje pierwszej litery „K” oraz pozbawiony litery

${ }^{15}$ Semkowicz, Paleografia tacińska, s. 346-356, 360.

${ }^{16}$ Pierwsza informacja dotycząca obchodu liturgicznego pojawia się dopiero na karcie $16 \mathrm{r}$ „Dominica post Nativitatem”. 
„H” wyraz „-ec” i litery „F” wyraz „-res”. W trzech miejscach rubryki uzupełniono, ale uczyniła to inna ręka i to czarnym inkaustem $(42 \mathrm{v}, 43 \mathrm{r})$. Dopiero po koniec tej części napotykamy na trzykrotne sporządzenie zapisów rubrycystycznych (k. 45v i 46v). Dwie ostatnie karty (47 i 48) zostały dołączone później. Na pierwszej z nich inną ręką i innym inkaustem dopisano dalszy ciąg tekstu lekcji z poprzedniej karty, dokonując w ten sposób jej praktycznego uzupełnienia, oraz - co wyraźnie zaznacza istniejąca tu rubryka - lekcję na „feria IV post Dominicam $\mathrm{Me}$ mento nostri Domine"17 (Eph 1, 16-21), która kończy się na następnej stronie ${ }^{18}$. To dowód na to, że dołączono od początku tylko połowę karty. Pozostałą przestrzeń strony, jak i całą ćwiartkę karty 48, zapisano później drobnym, odręcznym pismem.

W kodeksie występuje niemała liczba różnego rodzaju poprawionych błędów: skreślenia $(1 \mathrm{r}-\mathrm{cm}, 21 \mathrm{v}$ - peripsima, a nad tym miejscem napisane niestarannie: tempore, $24 \mathrm{r}$ - sua, templi, eius, $28 \mathrm{v}$ - bona illius, $29 \mathrm{rv}$ - protegetur subtegmine illius et sub ramis illius morabitur, gdzie pomieszano zwroty $\mathrm{z}$ dwóch różnych wierszy, 30r - ipsius, a powyżej dopisano eius, ex, $31 \mathrm{r}$ - orare, a nad tym napisane: offerre, $32 \mathrm{v}$ - usque et, $33 \mathrm{v}$ - illam, $35 \mathrm{r}$ - autem, $35 \mathrm{v}$ - vobis, $39 \mathrm{r}$ - podwójne de manu), wymazania ( $12 \mathrm{v}$ - podwójne nomen, $22 \mathrm{v}-\mathrm{n}$ ze słowa intelligens, pozostawiając s w odosobnieniu, $38 \mathrm{r}$ - t $\mathrm{z}$ vite), uzupełnienia, najczęściej na marginesach ( $9 \mathrm{r}-\mathrm{o}$ nad $\mathrm{m}$ dla skrótu modo, $21 \mathrm{r}$ - horam, $21 \mathrm{v}$ - sumus, 23v - iracundie, $24 \mathrm{r}$ - templi, adimpleti, 24v - illarum, 26r - e nad -narrabo, 26v - o nad antiqrum, exquirentibus, parabolarum, gdyż w tekście jest nieudolnie poprawione: parabulorum, 27v i 35r - o nad g dla skrótu ergo, 28v - qui, 29v - e nad sci-tis, 30v - tes nad sacerdos, $31 \mathrm{v}$ - per pontificem, $33 \mathrm{v}$ - fortiter, $36 \mathrm{r}$ - tuo, $38 \mathrm{r}$ - spes), inne poprawki $(22 \mathrm{v}$ - poprawione oportet, $25 \mathrm{v}$ - laud- nad glori-abitur, $40 \mathrm{r}-$ quem poprawiono na quo z o nad linią dla skrótu quomodo), nierzadko wprowadzone duże litery w miejsce małych, wielokrotne pomyłki w nazwaniu księgi (11 razy) ${ }^{19}$, z której pochodzi tekst lekcji, jeśli w ogóle podano jej tytuł. Dwukrotnie podano ten sam obchód stosując odmienne określenia: „Dominica post Nativitatem” i „Dominica infra octavam Nativitatis” - ale w pierwszym przypadku podano tylko incipit lekcji, zaś w drugim już pełny jej tekst.

Wśród osobliwości pisarskich uwagę zwracają słowa: „Epiphenie”, „Epipheniam” (17r, 18r, 19r, 20v)) oraz odmiennie zapisywane zwroty ,ad chorinthios” (45v) i ,ad Korinthios” (46v) w tytułach lekcji. Często występuje skrót „1. e. b. p. a.”, to znaczy „lectio epistolae beati Pauli apostoli”, zaś „In illo t. d. i. d. s.” (42r) - „In illo tempore dixit Jesus discipulis suis”, zastosowany został tylko jeden raz

${ }^{17}$ Środa po 4 Niedzieli Adwentu. Nie każdego roku ma miejsce taki obchód liturgiczny, dlatego uzasadnione jest powyższe uzupełnienie i to w tak nietypowym miejscu. Na karcie 10r, na marginesie obok tekstu lekcji na wigilię Narodzenia Pańskiego, drobnym czerwonym pismem zanotowano: „epistolam qui est in fine de feria IV”, co oznacza, że - odsyłając do lekcji umieszczonej na końcu księgi - wpisu tego dokonano już po dołączeniu kart 47 i 48 . Ponadto, poniżej umieszczony zwrot „Non cesso” (zwykłym inkaustem) jest incipitem tej lekcji.

${ }^{18}$ Kolumna na tej karcie jest szersza niż na poprzednich $(120 / 115 \mathrm{~mm})$ i na $47 \mathrm{r}$ ma już tylko 11 wierszy, a $47 \mathrm{v}-7$.

${ }^{19}$ Karty 3v, 4r, 4v, 5v, 6r, 12r, 14r, 16v, 17r, 21r, 34r. 
w odniesieniu do jedynej ewangelii, która umieszczona została $\mathrm{w}$ tym lekcjona$\mathrm{rzu}^{20}$. W tekście (tylko na kartach $1 \mathrm{r}$ i $20 \mathrm{v}-40 \mathrm{v}$ ) występuje dosyć dużo znaków tonicznych, zaznaczonych czarnym inkaustem nad liniami tekstu, co wskazuje na pewien - nieznany nam dziś - sposób czytania, analogiczny lub tożsamy z tym, który w innych lekcjonarzach pozostawił wyraźniejsze ślady.

Również ten lekcjonarz nie posiada kalendarza liturgicznego. Teksty czytań ułożone są według następującego porządku: od 1 Niedzieli Adwentu do 2 Niedzieli po Epifanii (k. 1-20v), teksty wspólne: o męczennikach, wyznawcach, dziewicach (k. 21r-36r), lekcje na msze wotywne na poszczególne dni tygodnia, z wyjątkiem niedzielnej de Trinitate (k. 36r-38v), na msze w różnych potrzebach (k. $38 \mathrm{v}-44 \mathrm{r}$ ) i w mszach za zmarłych (k. 44r-46v). Z aktualnej zawartości tego Lectionarium wynika, że to, co z niego pozostało jest tylko częścią większej całości, z której zachowały się początkowe i końcowe karty. Ostatnie słowa karty 20v: „karitatem fraternitatis invicem diligentes honorem invicem perveni[entes]” (Rm $12,10)$, to niedokończona lekcja z 2 Niedzieli po Epifanii, natomiast pierwsze słowa karty $21 \mathrm{r}$ : „firma sit pro vobis scientes quoniam sicut socii passionum estis sic et consolacionis erimus" (2Cor 1,7), to ostatni wiersz lekcji wspólnej o męczennikach. Można przypuszczać, że pierwotny kodeks pod pewnymi względami był bogatszy od późniejszego Epistolare z 1500 r. Zachowuje rozróżnienie w tekstach wspólnych na ,de una virgine" i ,de pluribus virginibus”, nadto proponuje w zbiorze o jednej dziewicy 1 lekcję więcej (2Tim 4, 17-18) do wyboru. Podaje również lekcje w mszach za biskupa (1 Tim 3, 1-7a), za króla (Ier 22, 3-4) i na czas wojny (Is $37,1-7)$.

Jeżeli piąta składka pochodzi z innego kodeksu - a wiele na to wskazuje - to jej dołączenie do księgi zapewne nie było przypadkowe. Ostatnia karta (40) części podstawowej zawiera pełną lekcję, a po niej pozostaje jedna trzecia strony nie zapisanej, co raczej nie zdarza się. Prawdopodobnie księga nie została dokończona, co próbowano zrekompensować dodaniem części pochodzącej z innego kodeksu. Bowiem dalsze karty (41-46) zawierają te lekcje, które - sądząc po innych tego typu księgach - powinny znajdować się właśnie w tym miejscu lekcjonarza. I chociaż ujawniają oczywiste braki, to spełniają w nim swoją funkcję. Pierwsza strona tej składki zaczyna się bezpośrednio od słów: ,habemus ad invicem et sanguis Iesu" (1Io 1,7b), które pochodzą ze środka zdania i są dalszym fragmentem jednej z lekcji odczytywanych w mszach za grzeszników - pro peccatis (1Io 1, 5b-9). Oznacza to, że istniały jakieś karty poprzedzające, tak samo, jak istniały i następujące. Ostatnia bowiem strona również zawiera tekst niedokończony - jest to początek lekcji (Act 1, 12-13a), którą odczytywano w mszach wotywnych o Matce Bożej w sobotę. Brakująca jego część $(1,13 b-14)$ najpierw dopisano odręcznym drobniutkim pismem poniżej strony, a następnie staranną kaligrafią na dołączonej później połówce karty 47, o czym już wyżej wspomniano. Natomiast ostatnią kartę (48) trudno uznać za integralną część lekcjonarza. Zawiera ona treść trzech lekcji: na święto Nawiedzenia Matki Bożej (Ct 2, 8b-14), na wigilię tego

${ }^{20}$ Lc 12, 42-44 oraz incipit drugiej Mt 10, 5 
święta (Apc 12, 1-5) 21 i z księgi Mądrości Syracha 31, 8-11, który to fragment wówczas umieszczano w zbiorze tekstów wspólnych o jednym męczenniku.

Nie wiadomo, kto sporządził ten kodeks. Dwie zasadnicze części wskazuja wyraźnie na dwóch różnych pisarzy, a prawdopodobnie uzupełnienia, zwłaszcza odręczne, pochodzą od innych jeszcze osób. Również wziąc trzeba pod uwagę fakt zebrania i połączenia w jedną całość niejednolitych elementów, co mogło być dziełem znowuż innej osoby, ale trudno określić, kiedy to się stało. Pismo wskazuje, że dzieło powstało w XIV wieku, zaś ostateczne złożenie bardzo niekompletnej księgi nie później niż w XV wieku, kiedy rękopiśmienne lekcjonarze były jeszcze w użyciu. Ze względu na zupełny brak sanctorale nie da się w oparciu o wewnętrzną treść rękopisu ustalić miejsca jego pochodzenia.

\section{Epistolare - KP 222}

Epistolare również nie posiada strony tytułowej, zaś pierwsza zachowana karta rozpoczyna się bezpośrednio lekcją na 1 Niedzielę Adwentu. Kodeks posiada jednak własny tytuł - „Epistolarum Liber” - który został umieszczony wśród różnorodnych zdobień wytłoczonych na oryginalnej oprawie. Obleczone cienką skórą (już nieco podniszczona) deseczki o rozmiarach $245 \times 355 \times 8 \mathrm{~mm}$ obustronnie zabezpieczają księgę, dodatkowo wzmocnioną na narożnikach pięcioma solidnymi mosiężnymi okuciami; po pozostałych trzech zachowały się tylko wyraźne ślady. Podobne ślady na środku oprawy, tak przedniej jak i tylnej, wskazują na jeszcze jakieś inne metalowe elementy - prawdopodobnie ozdobne - które niegdyś tam były umieszczone. Odłączone znacznie później od oprawy zabezpieczyły fragmenty złocenia wklęsłych tłoczeń na skórze na przedniej stronie i srebrzenia na tylnej. Ponadto jeszcze inne ślady informują nas, że księga zaopatrzona była w dwie klamry spinające ją i zamykające. Jej grzbiet zabezpieczony jest oddzielnym innym kawałkiem skóry. Zachowany w bardzo dobrym stanie kodeks posiada 134 pergaminowe karty w dziewięciu składkach (poszytach) składających się z 8 arkuszy (octernion), czyli 16 kart każdy, bardzo mocno ze sobą spiętych i przytwierdzonych do oprawy. Wyjątek stanowi składka pierwsza, z której wycięto cztery karty początkowe, i ostatnia, z której usunięto ich aż sześć, o czym świadczą pozostawione ich resztki. Karty o rozmiarach $230 \times 335 \mathrm{~mm}$ i nierównej grubości ponumerowane zostały współczesną ręką cyframi arabskimi w prawych górnych rogach. Na kartach można dostrzec ślady prac związanych z wyprawianiem pergaminu, to znaczy tu i ówdzie występujące pofałdowania, pęknięcia, otwory i pozostałości po zszyciach.

Kodeks jest liniowany - zapis na stronie tworzy zwarta kolumna o rozmiarach $150 \times 235 \mathrm{~mm}$, którą wyznacza widoczny kontur delikatnych poziomych i pionowych linii tworzących ramkę. Takie same linie - leżące w odległości $10 \mathrm{~mm}$ od siebie - wyznaczały miejsce poszczególnym wierszom, których przewidziano na każdej stronie 24. Litery krótsze mają $5 \mathrm{~mm}$ wysokości, dłuższe 8-9 mm. Pismo

\footnotetext{
${ }^{21}$ Bez wierszy 12, 3-4.

${ }^{22}$ Polkowski, Katalog rękopisów, s. 39; Boguniowski, Rozwój historyczny ksiag, s. 98-102.
} 
nierzadko wychodzi poza prawy margines, mimo dodatkowej pionowej linii, poszerzającej kolumnę obustronnie o 2-4 mm i dającej pisarzowi większą swobodę. Trochę mniejszymi literami $(4 \mathrm{~mm})$ zapisano incipity antyfon na wejście na niektóre dni ${ }^{23}$. Natomiast na kilku stronach, w części zawierającej lekcje na dni świętych, zastosowano drobne $(2 \mathrm{~mm})$ odręczne pismo, mieszcząc dwa wiersze tekstu w jednej przewidzianej konturem linii, co zostało podyktowane praktycznym tylko charakterem zawartych tam informacji (imię świętego i incipit lekcji, którą należało zaczerpnąc z części tekstów wspólnych - „commune”), a więc nie był to tekst przeznaczony do odczytania $\mathrm{w}$ ramach liturgii ${ }^{24}$.

W kodeksie znajdują się 22 ozdobne inicjały, które ujmują w kolorowy prostokąt początkową literę tekstu lekcji. Tym niezbyt starannie wykonanym inicjałom o różnej wielkości (od $23 \times 28$ do $51 \times 63 \mathrm{~mm}$ ), wzbogaconym kawałkami złota płatkowego, towarzyszą bogate - również kolorowe - ornamenty kwiatowe, jakby łodygami swoimi wyprowadzone z owych prostokątów. Taką dekorację posiadają tylko te strony, na których umieszczono inicjał ozdobny ${ }^{25}$. Pierwsza strona kodeksu wyróżnia się od wszystkich pozostałych nie tylko inicjałem o największych rozmiarach i najbogatszą ornamentyką wypełniającą całą wolną przestrzeń wokół kolumny tekstu, ale zwłaszcza złotą ramką, okalającą stronę i przeplatająca się z kolorowymi elementami dekoracyjnymi. Wśród nich wrysowany został znak herbowy, zapewne autora księgi. W kodeksie są jeszcze inne rodzaje inicjałów: większe, na wysokość dwóch linii, rozpoczynające lekcję od takich typowych zwrotów jak „Fratres”, „Ch(K)arissimi”, „Hec dicit Dominus”, „In diebus illis” (w tym ostatnim przypadku, litera „I” bardzo często wydłużona jest znacznie, aż do kilku linii, przybierając niejednokrotnie formy fantazyjne ${ }^{26}$, oraz mniejsze, zajmujące wysokość jednej linii, w kształtach przyjętych wówczas standardów pisarskich, a rozpoczynające właściwy tekst lekcji. W przypadku obydwóch rodzajów inicjałów użyto na przemiennie farby czerwonej i niebieskiej.

Pismo w całym lekcjonarzu jest ładne i staranne, umożliwiające swobodne odczytanie tekstu. Jest to gotycka bastarda, która łączy w sobie elementy kursywy $\mathrm{z}$ teksturą ${ }^{27}$. Wykonane zostało czarnym inkaustem oraz - w przypadku tytułów lekcji i informacji rubrycystycznych - czerwoną farbą (cynobrem). Pierwsze litery zdania lub biblijnego wiersza zostały podcieniowane żółtym lub czerwonym kolorem. Układ stron podporządkowany jest zasadzie oszczędności. Dlatego nie ma na nich żadnych akapitów i odstępów, wszystko zapisane jest w jednym ciagu,

${ }^{23}$ Incipity antyfon na wejście (introitów) zaznaczono w okresie Adwentu - 2, Narodzenia Pańskiego - 11, po okresie Narodzenia Pańskiego - 5, w okresie Wielkiego Postu - 42, Wielkanocnym - 17, po okresie Wielkanocnym - 11; razem: 88.

${ }^{24}$ Karty: 99v, 100r, 102v, 103v, 104r, 104v, 105r, v, 106r, v, 107r, v, 109r, v, $111 \mathrm{r}$.

${ }^{25}$ Karty: 1r, 8v, 11r, 16r, 21r, 52v, 60r, 61v, 64v, 69r, 97r, 98r, 98v, 103r, 103v, 106r, 110v, 112r, $114 \mathrm{v}, 121 \mathrm{v}$ (ornament bardzo skromny), 124v (wyjątek - brak jakiegokolwiek ornamentu), 128v.

${ }^{26}$ Dodano również analogiczne zwroty kończące lekcję, np.: „In Christo Jesu Domino nostro”, „Per Jesum Christum Dominum nostrum”.

${ }^{27} \mathrm{O}$ charakterystyce pisma zob. Kolektarz wawelski sprzed 1526 roku, świadek liturgii Kościoła krakowskiego w XV, XVI i XVII wieku, oprac. S. Fedorowicz, w: Monumenta Sacra Polonorum, t. 3, Kraków 2007, s. 71. 
a rubryki zapowiadające kolejną lekcję następują zwyczajnie po kropce kończącej poprzednią.

Pisarz Epistolare popełnił szereg błędów. Pomijając uchybienia dotyczące samego tekstu biblijnych czytań, wskazujemy tylko na te, które zakradły się na poziomie wyłącznie technicznym ${ }^{28}$. Sporządzając księge pisarz kilkakrotnie gubił pewne słowa lub części słów, które później dopisywał drobnymi literami, uzupełniając w ten sposób uszkodzony tekst. Czynił to najczęściej nad miejscem, z którego słowo „wypadło" lub na marginesie: 1r - Pauli (czarnym inkaustem w zapisie rubrycystycznym), $3 \mathrm{v}-\mathrm{t}$ (czyli tutaj „tibi”), $6 \mathrm{v}-$ con nad - placuit, $11 \mathrm{v}-$ te nad novita-, $14 \mathrm{r}$ - Deus, $14 \mathrm{v}$ - per, $40 \mathrm{r}-$ meum, $43 \mathrm{r}-$ te, $87 \mathrm{v}-$ die, $93 \mathrm{v}-$ tes do Scien-, 94v - ctu nad infru-osis, 95r - quo, 100v - ad, 103r - eius, propera, 104r - ta nad Stragula-, $115 \mathrm{r}$ - ex, 125r - suis, $128 \mathrm{r}$ - eo, 131r - quoniam (z zastosowaniem skrótu paleograficznego), $133 \mathrm{r}$ - sacrificium. W tekście występują też skreślenia $(1 \mathrm{r}$ - podwójne ante, $1 \mathrm{v}$ - in, $10 \mathrm{r}$ - podwójne non, $19 \mathrm{v}$ - podwójne eis, $47 \mathrm{r}$ - podwójne autem), wymazania (104r - litera w słowie Stra-gula, $115 \mathrm{r}$ - autem, eorum, $116 \mathrm{v}-\mathrm{ad}$ ) oraz inaczej poprawione błędy $(92 \mathrm{r}$ - na marginesie zapisano collucacio obok istniejącego $\mathrm{w}$ tekście conlucacio, $106 \mathrm{v}$ - przekreślono w rubryce corinthos i dopisano galatas czarnym inkaustem), a nawet nie poprawione, jak powtórnie napisany zwrot: „Joannes septem ecclesiis que sunt in asia” (107r). Popełnione pomyłki odnoszą się także do nazewnictwa biblijnych ksiąg, z których wzięto lekcje, a zdarzyło się to 5-krotnie ${ }^{29}$. Natomiast w przypadku którejkolwiek księgi mądrościowej zawsze zastosowano to samo określenie: „Liber Sapientie”, tak samo, jak mają obydwa wcześniejsze lekcjonarze.

Uwagę zwracają niektóre rubryki umieszczone w Epistolare. Oprócz tych zwykłych, zapowiadających każdą lekcję z konkretnej księgi biblijnej, znajdujemy nieliczne informacje typu: „legitur (legantur, lege) in modum lectionis”, ,in modum epistole (pronunties)”, ,pronuntiatur sine titulo”, albo zwroty: ,ad missam”, ,in missa”, ,prophetia”, „require”, ,in quatuor temporibus”; czasem zapisane nie rubrem, ale czarnym inkaustem. Modum lectionis i modum epistole określają dwa różne sposoby odczytywania lekcji. Były to - już wcześniej wspomniane - tak zwane toni recitativi, na które wskazują drobne znaki toniczne rozsiane rzadko po całym kodeksie, wykonane rubrem i umieszczone w tekście nad wierszem w odpowiednim miejscu, jako istotna wskazówka dla lektora ${ }^{30}$.

${ }^{28}$ Uwagi na temat samej pisowni i stosowanych skrótów zob. tamże, s. 70. W naszym kodeksie występują skrócenia tytułów ksiagg, z których brano lekcje, np. takie: L. e. b. p. a. ad corinthos - Lectio epistole beati pauli apostoli ad corinthos, albo L. 1. apok. - Lectio libri apokalipsis. A także znany już z Lectionarium KP 21: In illo t. d. i. di. suis, i zastosowany w tym samym kontekście, k. 132v.

${ }^{29}$ Wigilia Epifanii, poniedziałek po Niedzieli Palmowej, środa po 10 Niedzieli post Trinitate, 17 Niedziela, środa po 21 Niedzieli. Do pomyłek zaliczyć należy również dwukrotne podanie lekcji na święto Zwiastowania: chronologicznie w sanctorale i pomiędzy tekstami czytań na msze wotywne.

${ }^{30} \mathrm{~W}$ mszałach krakowskich z 1515 r. i z 1532 r. występuje jeszcze inne określenie: „legatur in modum evangelii" zastosowane do niewielkiego fragmentu opisu męki Pańskiej we wszystkich czterech Ewangeliach (k. LXXVIr,LXXXIXr, LXXXIIv, LXXXXr; k. 73r, 77r, 80v, 88v). 
Lekcjonarz nie posiada kalendarza liturgicznego, nie podano również dat obchodów świąt stałych. Zawiera czytania na cały rok, rozłożone według następującego schematu: najpierw de tempore (k. 1r-96v), dalej de sanctis (k. 96v-109v), później lekcje mszy wotywnych na każdy dzień tygodnia (k. 109v-111r), „In Dedicatione Eclesie” (k. 111r-112r), następnie „Epistole sanctorum communes” (k. 112r-130v), wreszcie lekcje mszy w różnych potrzebach (k. 130v-133r) i za zmarłych $(133 \mathrm{r}-134 \mathrm{v})$. Lekcje własne mają poszczególne dni de tempore (wszystkie niedziele, święta, kolejne dni Wielkiego Postu, oktawy wielkanocnej i oktawy Zesłania Ducha Świętego oraz środy i piątki pozostałych mocnych okresów liturgicznych) i tylko 24 obchody świętych. W pozostałe dni de sanctis rubryki lekcjonarza odsyłają do tekstów wspólnych; bywa i tak, że gdy perykopy własne się powtarzają, redaktor również odsyła do raz zapisanego tekstu i nie przepisuje go powtórnie.

Warto odnotować ciekawsze zapisy dotyczące zawartości merytorycznej. Otóż obok lekcji Wielkiego Czwartku na marginesie dopiano: „De Corpore Christi”, to znaczy, że tę lekcję należało odczytać w wymienione święto, zaś po święcie Sancta Trinitate, również na marginesie zaznaczono: „De Corpore Christi Epistola. Queratur in Cena Domini”, czyli po raz drugi informację o tym samym znaczeniu. Ciekawego zabiegu dokonał redaktor księgi w przypadku lekcji na 23 niedzielę po Trójcy Świętej i na obchód św. Klemensa. Na te dni przypadał ten sam tekst z Listu do Filipian, ale w obu przypadkach zapis jest niepełny. Dla pierwszego z tych dni mamy początkowy fragment lekcji, a dla drugiego końcowy. Jednak dopiski na marginesie informują precyzyjnie o konieczności powiązania obydwóch rozdzielonych części i odczytania pełnej perykopy ${ }^{31}$. W innym przypadku - lekcji na wtorkową mszę wotywną o Duchu Świętym - zaznaczono, że należy ją zaczerpnać z czytania na 10 niedzielę, ale tylko od połowy zapisanego tam tekstu (,in media epistola”, k. 109v). Nadto, chociaż księga z założenia zwiera tylko lekcje, to jednak - wyjątkowo - podano w tekstach wspólnych dwie ewangelie In anniversario consecrationis - ze św. Mateusza tylko incipit, zaś ze św. Łukasza pełny fragment, tak samo jak w lekcjonarzu KP 21.

Wykonawcą kodeksu jest Piotr Postawa z Proszowic ${ }^{32}$. Informację o tym pozostawił on sam wewnątrz księgi, aż trzykrotnie wprost odnotowując ten fakt: „Petrus Posthawa de Proszowicze vicarius Castri Cracoviensi scripsit”"33, „Petrus Proschouita vicarius scripsit 1500”34 i w kolofonie „Hoc Epistolare est scriptum Per me Petrum Postawa de Prossowicze Viccarium perpetuum ecclesie Cathedralis Cracoviensis. hoc anno salutis Millesimo quingentesimo. 1500"35. Epistolare sporządzono więc w środowisku Kościoła krakowskiego, dla katedry wawelskiej. W niej był używany i w jej archiwum znajduje się aktualnie.

${ }^{31}$ „Finem istius epistole habes infra in die s. Clementis post festum Sanctorum Omnium” (94r); „Initium istius epistole vide super Dominica 23 post Pent. Imitatores mei estote et” (109r).

${ }^{32}$ O Piotrze Postawie z Proszowic zob. Kolektarz wawelski sprzed 1526 roku, s. 72.

${ }^{33} \mathrm{~W}$ stopkach stron karty 30v i $31 \mathrm{r}$.

${ }^{34} \mathrm{~W}$ stopce k. $131 \mathrm{r}$.

${ }^{35}$ Kolofon na k. $134 \mathrm{v}$. 
Poniżej przedstawiamy pełny zestaw lekcji wszystkich trzech lekcjonarzy ${ }^{36}$. Ponieważ kompletny jest tylko najmłodszy z nich - Epistolare - dlatego układ i program perykop podajemy według schematu i zawartości tej księgi. Równolegle - dla porównania i porządku - umieszczamy te lekcje, które znajdują się w dwóch pozostałych lekcjonarzach.

Zestaw ten jest zgodny z tym, co zawierają późniejsze, szesnastowieczne krakowskie mszały drukowane. W części de tempore występują nieliczne i drobne różnice, które odnotujemy w stosownym miejscu w przypisach. Natomiast w części de sanctis sytuacja jest odmienna: jeśli zestaw tekstów własnych w mszałach pokrywa się dokładnie z tymi, które znajdują się w Epistolare, to jednak lekcje w nich dobrane dla mszy o poszczególnych świętych różnią się dosyć poważnie od tego, co zawierają lekcjonarze rękopiśmienne, chociaż zawsze są czerpane z niewiele różniącego się zbioru „commune”. Dlatego rezygnujemy ze szczegółowego przedstawienia tych odmienności, które uwzględnimy tylko w wyjątkowych i ciekawszych przypadkach ${ }^{37}$.

Porównanie trzech omawianych tutaj manuskryptów, które merytorycznie zawierają tę samą treść, pozwala na wyciagnięcie kilku dość oczywistych wniosków. Otóż, mimo, że każdy z tych lekcjonarzy powstawał w zupełnie innym czasie, to prawdopodobnie wszystkie sporządzono w tym samym miejscu, to znaczy w Krakowie. Wskazują na to liczne drobne podobieństwa natury redaktorskiej, choć, rzecz jasna, całkowicie o tym nie przesądzają. Przeglądając te księgi nie można uniknąć wrażenia, że kolejni pisarze korzystali z dzieł wykonanych już wcześniej przez swoich poprzedników. Popełniali niejednokrotnie te same błędy, odnotowywali w rubrykach takie same uwagi w odniesieniu do tych samych tekstów lub tych samych dni liturgicznych. Wiele też mówią zestawy czytań, które w częściach zachowanych - pokrywają się prawie całkowicie, co byłoby niechybnie nie do pomyślenia, gdyby rękopisy powstawały zupełnie gdzie indziej. Ich współzależność wydaje się być niewątpliwa, chociaż posiadają charakterystyczne dla siebie odrębności, będące wyciśniętym na nich piętnem epok, w których były sporządzane.

\begin{tabular}{|l|c|c|c|}
\hline \multicolumn{1}{|c|}{$\mathbf{1}$} & KP 22 & KP 21 & KP 20 \\
\hline Dominica I in Adventu & $\mathbf{2}$ & $\mathbf{3}$ & $\mathbf{4}$ \\
\hline feria IV & Iac 5, 7-10 & Iac 5, 7-10 & \\
\hline feria VI & 1Io 3, 21-24a & 1Io 3, 21-24a & \\
\hline $\begin{array}{l}\text { Dominica II in Adven- } \\
\text { tu }\end{array}$ & Rm 15, 4-13 & Rm 15, 4-13 & \\
\hline feria IV & Mal 3, 1-5. 4, 5-6a & Mal 3, 1-5. 4, 5-6a & \\
\hline
\end{tabular}

${ }^{36}$ Podobny zestaw czytań mszalnych de tempore (lekcji i ewangelii) na przykładzie mszałów krakowskich (nr 4 i nr 8 AKKK) przedstawił Boguniowski, Rozwój historyczny ksiag, s. 231-252.

${ }^{37}$ Oznaczenia i sigla biblijne według Biblia Sacra iuxta Vulgatam versionem, Stuttgart 1969. 


\begin{tabular}{|c|c|c|c|}
\hline 1 & 2 & 3 & 4 \\
\hline feria VI & $2 \mathrm{Pt} 3,8-14$ & $2 \mathrm{Pt} 3,8-14$ & \\
\hline $\begin{array}{l}\text { Dominica III in Ad- } \\
\text { ventu }\end{array}$ & 1 Cor $4,1-5$ & 1 Cor $4,1-5$ & \\
\hline $\begin{array}{l}\text { feria IV in quatuor } \\
\text { temporum }\end{array}$ & Is $2,2-5 ;$ Is $7,10-15$ & Is $2,2-5$; Is $7,10-15$ & \\
\hline feria VI & Is $11,1-5$ & Is $11,1-5$ & \\
\hline sabbato & $\begin{array}{c}\text { Is } 19,20 \mathrm{~b}-22 ; \text { Is } 35,1- \\
7 \mathrm{a} ;\end{array}$ & $\begin{array}{c}\text { Is } 19,20 \mathrm{~b}-22 ; \text { Is } 35,1- \\
7 \mathrm{a} ;\end{array}$ & \\
\hline Is $40,9-11$; Is 45, 1-8; & Is 40, 9-11; Is 45, 1-8; & & \\
\hline $\begin{array}{l}\text { Dn } 3,49-51^{1} ; 2 \text { Th } 2,1- \\
8\end{array}$ & $\begin{array}{c}\text { Dn } 3,49-51 ; 2 \text { Th } 2,1- \\
8\end{array}$ & & \\
\hline $\begin{array}{l}\text { Dominica IV in Ad- } \\
\text { ventu }\end{array}$ & Phil 4, 4-7 & Phil 4, 4-7 & \\
\hline feria IV $^{2}$ & Eph $1,16-21^{3}$ & Eph 1, 16-21 & \\
\hline Vigilia Nativitatis & Is $62,1-4 ; \mathrm{Rm} 1,1-6$ & Is $62,1-4 ; \mathrm{Rm} 1,1-6$ & \\
\hline \multirow[t]{2}{*}{ Nativitas Domini } & $\begin{array}{c}1 \text { msza: Is 9, 2.6-7; Tit } \\
2,11-15 \mathrm{a} \\
\end{array}$ & $\begin{array}{c}\text { Is 9, 2.6-7; Tit 2, 11- } \\
15 \mathrm{a}\end{array}$ & \\
\hline & $\begin{array}{c}2 \text { msza: Is } 61,1-3.62, \\
11-12 a ;\end{array}$ & Is $61,1-3.62,11-12 \mathrm{a}$ & \\
\hline \multirow[t]{2}{*}{ Tit 3, 4-7 } & Tit $3,4-7$ & & \\
\hline & $\begin{array}{c}3 \text { msza: Is } 52,6-10^{5} ; \\
\text { Hbr } 1,1-12\end{array}$ & $\begin{array}{c}\text { Is } 52,6-10 ; \mathrm{Hbr} 1,1- \\
12\end{array}$ & \\
\hline Stephani & Act $6,8-10.7,54-59$ & Act $6,8-10.7,54-59$ & \\
\hline Iohannis & Sir $15,1-6^{6}$ & Sir $15,1-6$ & \\
\hline Innocentium & Apc $14,1-5$ & Apc $14,1-5$ & \\
\hline \multicolumn{4}{|l|}{$\begin{array}{l}\text { Dominica infra octa- } \\
\text { vas }\end{array}$} \\
\hline Nativitatis & Gal 4, 1-7 & Gal 4, 1-7 & \\
\hline Circumcisio Domini & Gal 3, 23-4, 2 & $\begin{array}{c}\text { Col 1, 25b-28 lub Tit } \\
3,4-7\end{array}$ & \\
\hline Vigilia Epiphaniae & $\begin{array}{c}\text { Tit 3, 4-7 lub Rm 3, } \\
19-26^{7}\end{array}$ & $\begin{array}{c}\text { Tit 3, 4-7 lub Rm 3, } \\
19-26\end{array}$ & \\
\hline Epiphania Domini & Is $60,1-6$ & Is $60,1-6$ & Is $60,3 \mathrm{~b}-6^{8}$ \\
\hline \multicolumn{4}{|l|}{$\begin{array}{l}\text { Dominica infra octa- } \\
\text { vas }\end{array}$} \\
\hline Epiphaniae & $\mathrm{Rm} 12,1-5$ & $\mathrm{Rm} 12,1-5$ & $\mathrm{Rm} 12,1-5$ \\
\hline feria IV $^{9}$ & $\mathrm{Rm} 3,19-26$ & $\mathrm{Rm} 3,19-26$ & $\mathrm{Rm} 3,19-26^{10}$ \\
\hline feria VI & $2 \mathrm{Th} 3,13-16$ & $2 \mathrm{Th} 3,13-16$ & $2 \operatorname{Th} 3,13-16 \mathrm{a}^{11}$ \\
\hline Octava Epiphaniae & $\begin{array}{l}\text { Is } 25,1.35,1-2.10 . \\
41,18 .\end{array}$ & $\begin{array}{l}\text { Is } 25,1.35,1-2.10 . \\
41,18 .\end{array}$ & \\
\hline $52,13.12,3-5$ & $52,13.12,3-5$ & & \\
\hline $\begin{array}{l}\text { Dominica II post } \\
\text { Epiphaniam }\end{array}$ & Rm 12, 6-16a & Rm 12, 6-16a & $\operatorname{Rm~} 12,11-16 \mathrm{a}^{12}$ \\
\hline feria IV & Col 1, 25b-28 & Col 1, 25b-28 & \\
\hline feria VI & $1 \operatorname{Tim} 4,9-16$ & $1 \operatorname{Tim} 4,9-16$ & \\
\hline $\begin{array}{l}\text { Dominica III post } \\
\text { Epiphaniam }\end{array}$ & $\mathrm{Rm} 12,16 \mathrm{~b}-21$ & $\mathrm{Rm} 12,16 \mathrm{~b}-21$ & \\
\hline
\end{tabular}




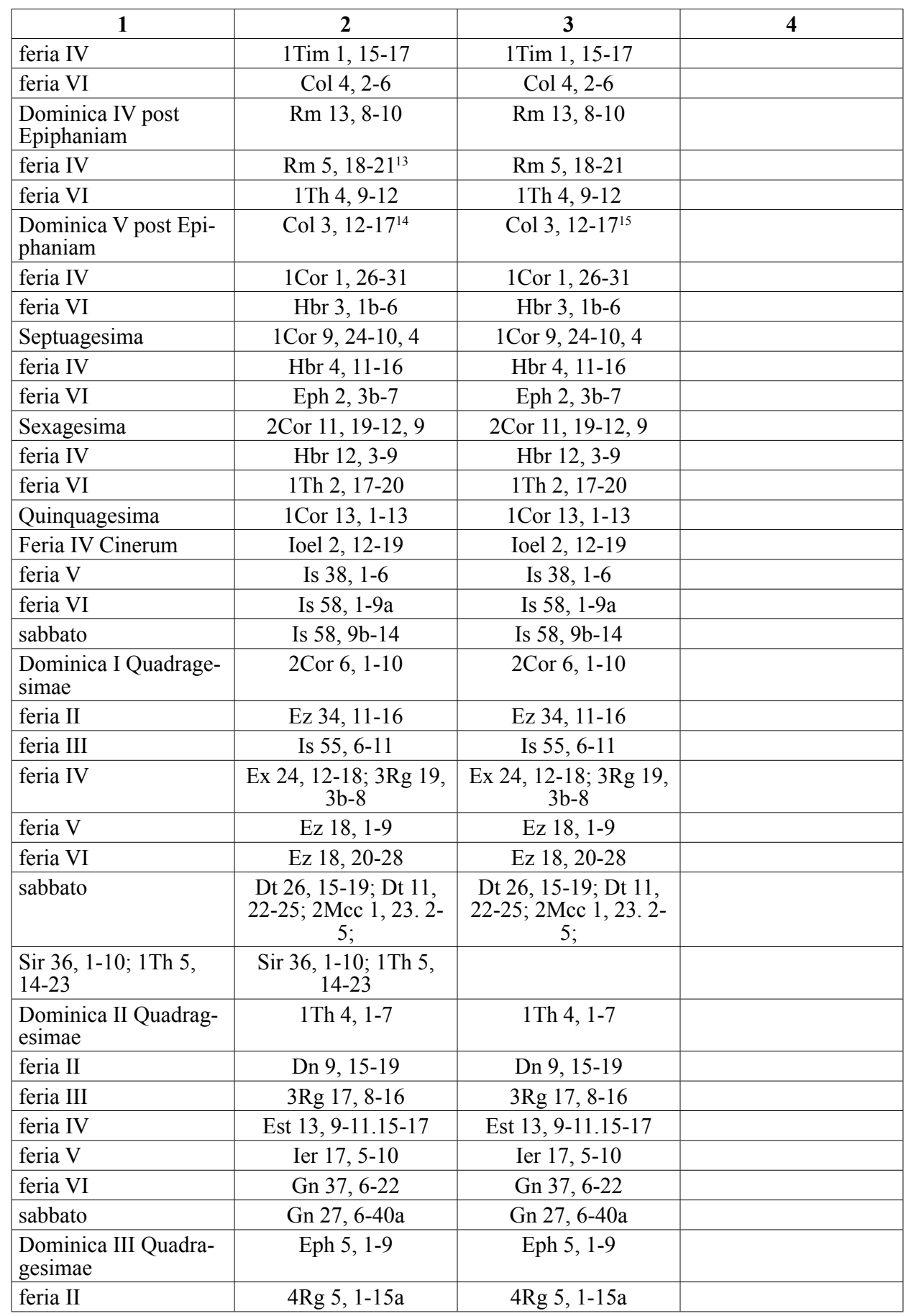




\begin{tabular}{|c|c|c|c|}
\hline 1 & 2 & 3 & 4 \\
\hline feria III & $4 \operatorname{Rg} 4,1-7$ & $4 \operatorname{Rg} 4,1-7$ & \\
\hline feria IV & Ex 20, 12-24 & Ex 20, 12-24 & \\
\hline feria $\mathrm{V}$ & Ier $7,1-7$ & Ier $7,1-7$ & \\
\hline feria VI & $\begin{array}{l}\mathrm{Nm} 20,2 b-3 a . \text { Ex } 17 \\
\text { 2. Nm 20,6-13 }\end{array}$ & $\begin{array}{l}\mathrm{Nm} 20,2 b-3 a . \text { Ex 17, } \\
\text { 2. Nm 20, 6-13 }\end{array}$ & \\
\hline sabbato & Dn $13,1-62$ & Dn $13,1-62$ & \\
\hline $\begin{array}{l}\text { Dominica IV Quadra- } \\
\text { gesimae }\end{array}$ & Gal 4, 22-31 & Gal 4, 22-31 & \\
\hline feria II & $3 \operatorname{Rg} 3,16-28$ & $3 \operatorname{Rg} 3,16-28$ & \\
\hline feria III & Ex $32,7-14$ & Ex $32,7-14$ & \\
\hline feria IV & $\begin{array}{c}\text { Ez 36, 23-28; Is } 1,16- \\
19\end{array}$ & $\begin{array}{c}\text { Ez 36, 23-28; Is 1, 16- } \\
19^{17}\end{array}$ & \\
\hline feria $\mathrm{V}$ & $4 \operatorname{Rg} 4,25-38 \mathrm{a}$ & $4 \operatorname{Rg} 4,25-38 \mathrm{a}$ & \\
\hline feria VI & $3 \operatorname{Rg~} 17,17 b-24$ & $3 \operatorname{Rg} 17,17 b-24$ & \\
\hline sabbato & Is $49,8-15$ & Is $49,8-15$ & \\
\hline $\begin{array}{l}\text { Dominica in Passione } \\
\text { Domini }\end{array}$ & Hbr 9, 11-15 & Hbr 9, 11-15 & \\
\hline feria II & Ion $3,1-10 \mathrm{a}^{18}$ & Ion $3,1-10 \mathrm{a}$ & \\
\hline feria III & Dn $14,28-41.6,27^{19}$ & Dn 14, 28-41. 6, 27 & \\
\hline feria IV & Lv 19, 11-19a & Lv 19, 11-19a & \\
\hline feria $\mathrm{V}$ & Dn 3, 34-45 & Dn $3,34-45$ & \\
\hline feria VI & Ier $17,13-18$ & Ier $17,13-18$ & \\
\hline sabbato & Ier $18,18-23$ & Ier $18,18-23$ & \\
\hline $\begin{array}{l}\text { Dominica in Ramis } \\
\text { Palmarum }\end{array}$ & $\begin{array}{l}\text { Ex 15, 27-16, 10 } \\
\quad \text { Phil } 2,5-11^{21}\end{array}$ & $\begin{array}{l}\text { Ex 15, 27-16, 1022; } \\
\quad \text { Phil } 2,5-11^{23}\end{array}$ & \\
\hline feria II & Is $50,5-10$ & Is $50,5-10$ & \\
\hline feria III & Ier $11,18-20$ & Ier $11,18-20$ & \\
\hline feria IV & $\begin{array}{c}\text { Is } 62,11 \mathrm{~b} .63,1-7^{24} \text {; Is } \\
53,1-12\end{array}$ & $\begin{array}{l}\text { Is } 62,11 \mathrm{~b} .63,1-7 \text {; Is } \\
53,1-12^{25}\end{array}$ & \\
\hline Feria V & 1Cor $11,20-32$ & 1Cor $11,20-32$ & \\
\hline Feria VI in Parasceve & $\begin{array}{l}\text { Os 6, 1-6 }{ }^{26} ; \text { Ex 12, 1- } \\
11\end{array}$ & $\begin{array}{c}\text { Os } 6,1-6^{27} ; \text { Ex } 12,1- \\
11\end{array}$ & \\
\hline Vigilia Paschalis & $\begin{array}{l}\text { Gn 1, 1-2, 2; Ex 14, } \\
\text { 24-15, 1a; Is 4, 1-6 }\end{array}$ & $\begin{array}{c}\text { Gn 1, 1-2, 2; Ex 14, } \\
\text { 24-15, 1a } a^{29} \text {;s 4, 1-6 }\end{array}$ & \\
\hline $\begin{array}{l}\text { Dt 31, 22-30; Col 3, 1- } \\
4\end{array}$ & Dt 31, 22-30; Col 3, $1-$ & & \\
\hline Dominica Paschalis & 1 Cor $5,7-8$ & 1 Cor $5,7-8$ & \\
\hline feria II & Act $1,15 \mathrm{a} .10,37-43$ & Act $1,15 \mathrm{a} .10,37-43$ & \\
\hline feria III & Act $13,16 a .26-33 a$ & Act $13,16 a .26-33 a$ & \\
\hline feria IV & $\begin{array}{l}\text { Act } 10,34 \mathrm{a} .13,16 \mathrm{~b} . \\
\quad 3,13-19^{32}\end{array}$ & $\begin{array}{c}\text { Act } 10,34 a \cdot 13,16 b . \\
3,13-19\end{array}$ & \\
\hline feria $\mathrm{V}$ & Act $8,26-40$ & Act $8,26-40$ & \\
\hline feria VI & $1 \mathrm{Pt} 3,18-22 \mathrm{a}$ & $1 \mathrm{Pt} 3,18-22 \mathrm{a}$ & \\
\hline sabbato & 1 Pt $2,1-10$ & 1 Pt $2,1-10$ & \\
\hline $\begin{array}{l}\text { Dominica I post Pa- } \\
\text { scha }\end{array}$ & 1Io $5,4-10 \mathrm{a}$ & 1Io 5, 4-10a & \\
\hline
\end{tabular}




\begin{tabular}{|c|c|c|c|}
\hline 1 & 2 & 3 & 4 \\
\hline feria IV & Hbr $13,17-21$ & Hbr $13,17-21$ & \\
\hline feria VI & $1 \operatorname{Tim} 6,17-21$ & $1 \operatorname{Tim} 6,17-21$ & \\
\hline $\begin{array}{l}\text { Dominica II post Pa- } \\
\text { scha }\end{array}$ & $1 \mathrm{Pt} 2,21 \mathrm{~b}-25$ & $1 \mathrm{Pt} 2,21 \mathrm{~b}-25$ & \\
\hline feria IV & $1 \mathrm{Pt} 1,18-25 \mathrm{a}$ & $1 \mathrm{Pt} 1,18-25 \mathrm{a}$ & \\
\hline feria VI & $\mathrm{Rm} 15,14-17$ & $\mathrm{Rm} 15,14-17$ & \\
\hline $\begin{array}{l}\text { Dominica III post } \\
\text { Pascha }\end{array}$ & $1 \mathrm{Pt} 2,11-19 \mathrm{a}$ & $1 \mathrm{Pt} 2,11-19 \mathrm{a}$ & \\
\hline feria IV & 1Io $2,1-8$ & 1Io $2,1-8$ & \\
\hline feria VI & Col 2, 4-7a & Col 2, 4-7a & \\
\hline $\begin{array}{l}\text { Dominica IV post } \\
\text { Pascha }\end{array}$ & Iac $1,17-21$ & Iac $1,17-21$ & \\
\hline feria IV & 1 Th $5,5-11$ & 1Th $5,5-11$ & \\
\hline feria VI & $1 \mathrm{Th} 5,1-5,5 \mathrm{a}$ & $1 \mathrm{Th} 5,1-5,5 \mathrm{a}$ & \\
\hline $\begin{array}{l}\text { Dominica V post Pa- } \\
\text { scha }\end{array}$ & Iac $1,22-27$ & Iac $1,22-27$ & \\
\hline $\begin{array}{l}\text { In Rogationibus [feria } \\
\text { II] }\end{array}$ & Iac $5,16-20$ & Iac $5,16-20$ & \\
\hline feria III & $1 \operatorname{Tim} 2,1-7$ & - & \\
\hline Vigilia Ascensionis & $\begin{array}{c}\text { Eph 4, 7-1333; Act 4, } \\
32-35^{34}\end{array}$ & $\begin{array}{c}\text { Eph 4, 7-13; Act 4, 32- } \\
35\end{array}$ & \\
\hline Ascensio Domini & Act $1,1-11$ & Act $1,1-11$ & \\
\hline feria VI & Eph 4, 7-13 35 & Eph 4, 7-13 ${ }^{36}$ & \\
\hline $\begin{array}{l}\text { Dominica VI post } \\
\text { Pascha }\end{array}$ & $1 \mathrm{Pt} 4,7 \mathrm{~b}-11 \mathrm{a}$ & $1 \mathrm{Pt} 4,7 \mathrm{~b}-11 \mathrm{a}$ & \\
\hline Infra hebdomadam $^{37}$ & Hbr 2,9b-3, 1 & Hbr 2,9b-3, 1 & \\
\hline Vigilia Pentecostes & $\begin{array}{l}\text { Rdz 22, 1-19; Dt 31, } \\
\text { 22-30; Is 4, 1-6; }\end{array}$ & $\begin{array}{l}\text { Rdz 22, 1-19; Dt 31, } \\
\text { 22-30; Is 4, 1-6; }\end{array}$ & \\
\hline $\begin{array}{l}\text { Bar 3, 9-38; Act 19, 1- } \\
8\end{array}$ & $\begin{array}{c}\text { Bar 3, 9-38; Act 19, } 1- \\
8^{38}\end{array}$ & & \\
\hline Pentecostes & Act $2,1-11$ & Act $2,1-11$ & \\
\hline feria II & Act $10,34 a{ }^{39} 42-48 a$ & Act $10,34 a \cdot 42-48 \mathrm{a}$ & \\
\hline feria III & Act $8,14-17$ & Act $8,14-17$ & \\
\hline $\begin{array}{l}\text { feria IV quatuor tem- } \\
\text { porum }\end{array}$ & $\begin{array}{c}\text { Sap 1, 1-7; Act 2, 14- } \\
21\end{array}$ & $\begin{array}{c}\text { Sap 1, 1-7; Act 2, 14- } \\
21\end{array}$ & \\
\hline feria $\mathrm{V}$ & Act $8,5-8^{40}$ & Act $8,5-8$ & \\
\hline feria VI & Act $2,22-28$ & Act $2,22-28$ & \\
\hline sabbato & $\begin{array}{l}\text { Ioel 2, 28-32a; Lv 23, } \\
\text { 10-11.15-17.21; }\end{array}$ & $\begin{array}{c}\text { Ioel 2, 28-32a; Lv 23, } \\
\text { 10-11.15-17.21; }\end{array}$ & \\
\hline $\begin{array}{l}\text { Ex 3, 15a. Dt 6, 6. 26, } \\
\text { 1-3a.7b-11; }\end{array}$ & $\begin{array}{c}\text { Ex 3, 15a. Dt 6, 6. 26, } \\
\text { 1-3a.7b-11; }\end{array}$ & & \\
\hline $\begin{array}{l}\text { Lv 23, 10a. 26, 3-12; } \\
\text { Dn 3, 49-51 }\end{array}$ & $\begin{array}{l}\text { Lv 23, 10a. 26, 3-12; } \\
\text { Dn 3, 49-51; }\end{array}$ & & \\
\hline Act $13,44 b-52$ & Act $13,44 \mathrm{~b}-52$ & & \\
\hline Octava Pentecostes ${ }^{42}$ & Apc 4, 1-10a & $\begin{array}{l}\text { Apc } 4,1-10 \mathrm{a} \text { (cui } \\
\text { placet) }\end{array}$ & \\
\hline Sancte Trinitatis & $\mathrm{Rm} 11,33-36$ & $\mathrm{Rm} 11,33-36^{43}$ & \\
\hline
\end{tabular}




\begin{tabular}{|c|c|c|c|}
\hline 1 & 2 & 3 & 4 \\
\hline Corporis Christi & 1 Cor $11,20-32^{44}$ & 1 Cor $11,23-29^{45}$ & \\
\hline $\begin{array}{l}\text { Dominica I post Trini- } \\
\text { tatis }\end{array}$ & 1Io 4, 8b-21 & 1Io 4, 8b-21 & \\
\hline feria $I^{46}$ & Col 3, 5-11 & Col 3, 5-11 & \\
\hline feria VI & Gal 3, 6-11 & Gal 3, 6-11 & \\
\hline $\begin{array}{l}\text { Dominica II post Tri- } \\
\text { nitatis }\end{array}$ & 1Io 3, 13-18 & 1Io $3,13-18$ & \\
\hline feria IV & $\mathrm{Rm} 5,1-5$ & $\mathrm{Rm} 5,1-5$ & \\
\hline feria VI & Eph 2, 4-10 & Eph 2, 4-10 & \\
\hline $\begin{array}{l}\text { Dominica III post } \\
\text { Trinitatis }\end{array}$ & $1 \mathrm{Pt} 5,6-11$ & $1 \mathrm{Pt} 5,6-11$ & \\
\hline feria IV & Col 3, 17-24 & $\mathrm{Col} \mathrm{3,17-24}$ & \\
\hline feria VI & Iac $2,1-9 a$ & Iac $2,1-9 \mathrm{a}$ & \\
\hline $\begin{array}{l}\text { Dominica IV post } \\
\text { Trinitatis }\end{array}$ & $\mathrm{Rm} 8,18-23$ & $\operatorname{Rm} 8,18-23$ & \\
\hline feria IV & Eph 1, 16-21 & Eph 1, 16-21 & \\
\hline feria VI & Iud 5-13 & Iud 5-13 & \\
\hline $\begin{array}{l}\text { Dominica V post Tri- } \\
\text { nitatis }\end{array}$ & $1 \mathrm{Pt} 3,8-15 \mathrm{a}$ & 1 Pt $3,8-15 \mathrm{a}$ & \\
\hline feria IV & $1 \operatorname{Tim} 2,1-7$ & $1 \operatorname{Tim} 2,1-7$ & \\
\hline feria VI & Iac 2, 14-17 & Iac 2, 14-17 & \\
\hline $\begin{array}{l}\text { Dominica VI post } \\
\text { Trinitatis }\end{array}$ & $\operatorname{Rm} 6,3-11$ & $\operatorname{Rm} 6,3-11$ & \\
\hline feria IV & Hbr $12,28 b-13,8$ & Hbr $12,28 b-13,8$ & \\
\hline feria VI & Iac $3,14-18$ & Iac $3,14-18$ & \\
\hline $\begin{array}{l}\text { Dominica VII post } \\
\text { Trinitatis }\end{array}$ & Rm 6, 19-23 & Rm 6, 19-23 & \\
\hline feria IV & $\mathrm{Rm} 8,1-6$ & $\mathrm{Rm} 8,1-6$ & \\
\hline feria VI & Iac $4,7-10^{47}$ & Iac 4, 7-10 & \\
\hline $\begin{array}{l}\text { Dominica VIII post } \\
\text { Trinitatis }\end{array}$ & $\operatorname{Rm} 8,12-17 \mathrm{a}$ & $\operatorname{Rm} 8,12-17 \mathrm{a}$ & \\
\hline feria IV & Rm 5, 8-11a & Rm 5, 8-11a & \\
\hline feria VI & Hbr 3, 12-14 & Hbr 3, 12-14 & \\
\hline $\begin{array}{l}\text { Dominica IX post } \\
\text { Trinitatis }\end{array}$ & 1 Cor $10,6 b-13$ & 1 Cor $10,6 b-13$ & \\
\hline feria IV & $\mathrm{Rm}$ 6, 16-18 & Rm 6, 16-18 & \\
\hline feria VI & $1 \mathrm{Pt} 4,12-14$ & $1 \mathrm{Pt} 4,12-14$ & \\
\hline $\begin{array}{l}\text { Dominica X post Tri- } \\
\text { nitatis }\end{array}$ & 1 Cor $12,2-11$ & 1 Cor $12,2-11$ & \\
\hline feria IV & 1 Cor $15,39-46$ & 1 Cor $15,39-46$ & \\
\hline feria VI & Col 1, 21-25a & Col 1, 21-25a & \\
\hline $\begin{array}{l}\text { Dominica XI post } \\
\text { Trinitatis }\end{array}$ & 1 Cor $15,1-10 a^{48}$ & 1 Cor $15,1-10 \mathrm{a}$ & \\
\hline feria IV & 1 Cor $6,15-20$ & 1 Cor $6,15-20$ & \\
\hline feria VI & 1 Cor $9,19-22$ & 1 Cor $9,19-22$ & \\
\hline $\begin{array}{l}\text { Dominica XII post } \\
\text { Trinitatis }\end{array}$ & 2 Cor $3,4-9$ & 2 Cor 3, 4-9 & \\
\hline
\end{tabular}




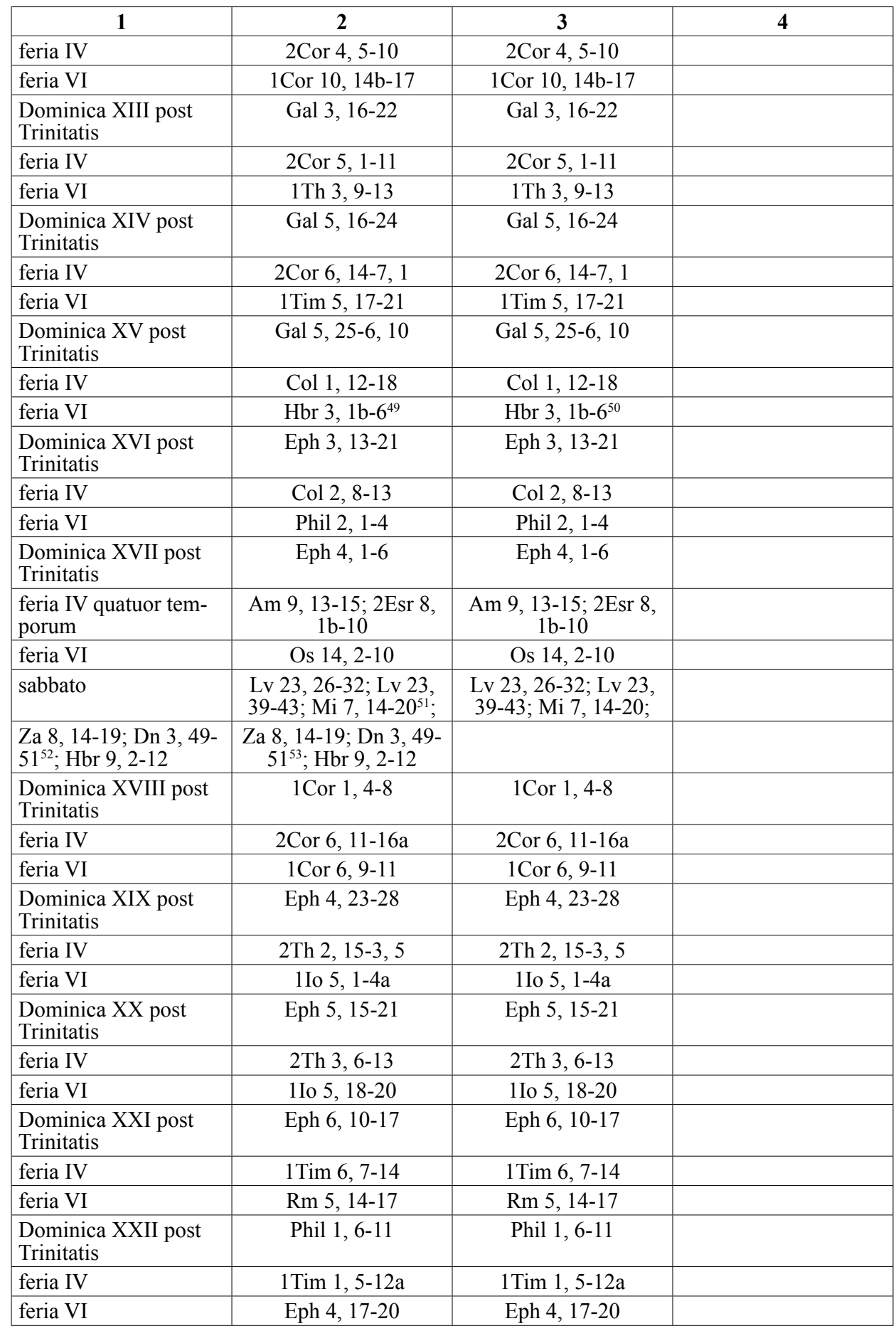




\begin{tabular}{|c|c|c|c|}
\hline 1 & 2 & 3 & 4 \\
\hline $\begin{array}{l}\text { Dominica XXIII post } \\
\text { Trinitatis }\end{array}$ & Phil $3,17-4,3^{54}$ & Phil 3, 17-4, 3 & \\
\hline feria IV & $2 \operatorname{Tim} 1,8-13$ & $2 \operatorname{Tim} 1,8-13$ & \\
\hline feria VI & Eph 5, 10-14 & Eph 5, 10-14 & \\
\hline $\begin{array}{l}\text { Dominica XXIV post } \\
\text { Trinitatis }\end{array}$ & Col 1, 9-14 & Col 1, 9-14 & \\
\hline feria IV & $\mathrm{Rm} 14,1-6 \mathrm{a}$ & $\mathrm{Rm} 14,1-6 \mathrm{a}$ & \\
\hline feria VI & Gal 3, 10-14a & Gal 3, 10-14a & \\
\hline $\begin{array}{l}\text { Dominica XXV post } \\
\text { Trinitatis }\end{array}$ & Ier $23,5-8$ & Ier $23,5-8$ & \\
\hline feria IV & 1Th $1,2-6$ & 1Th $1,2-6$ & \\
\hline feria VI & Col 1, 18-23 & Col 1, 18-23 & \\
\hline Luciae & $\begin{array}{c}\text { Sir } 51,13-17 \mathrm{a}^{55} ; 2 \text { Cor } \\
10,17-11,2\end{array}$ & $\begin{array}{c}\text { Sir 51, 13-17a; 2Cor } \\
10,17-11,2\end{array}$ & \\
\hline Vigilia Thomae & Prv $3,13-20$ & Prv $3,13-20$ & \\
\hline Thomae & $\begin{array}{c}\text { Eph 2, 19-22; Eph 1, } \\
3-8 \mathrm{a}\end{array}$ & $\begin{array}{c}\text { Eph 2, 19-22; Eph 1, } \\
3-8 \mathrm{a}\end{array}$ & \\
\hline Thomae & Hbr $5,1-6$ & Hbr $5,1-6$ & Hbr $5,1-6^{56}$ \\
\hline Silvestri & Sir $44,16 \ldots 45,20^{57}$ & Sir $44,16 \ldots 45,20^{58}$ & Sir $44,16 \ldots 45,20$ \\
\hline Felicis in Pincis & $2 \operatorname{Tim} 4,1-8$ & $2 \operatorname{Tim} 4,1-8$ & \\
\hline Marcelli & Hbr 7, 23-27 & Hbr 7, 23-27 & \\
\hline Priscae & Sap 7, 30b-8, 4a & Sap 7, 30b-8, 4a & \\
\hline Fabiani et Sebastiani & Hbr 11, 33-39a & Hbr 11, 33-39a & \\
\hline Agnetis & Sir 51, 1-12 59 & Sir 51, 1-12 & \\
\hline Vincentii & Is $43,1-5 \mathrm{a}$ & Is $43,1-5 \mathrm{a}$ & \\
\hline Conversio s. Pauli & Act $9,1-22^{60}$ & Act $9,1-22$ & \\
\hline Octava Agnetis & Sir $24,1-5.21 b-22$ & Sir 24, 1-5. 21b-22 & \\
\hline Purificatio Mariae & Mal 3, 1-4 & Mal 3, 1-4 & \\
\hline Agathae & $\begin{array}{c}\text { Sir } 51,13-17 \mathrm{a} ; \text { Sir } 51, \\
1-12\end{array}$ & $\begin{array}{c}\text { Sir 51, 13-17a; Sir 51, } \\
1-12\end{array}$ & \\
\hline Valentini & Prv $3,13-20$ & Prv $3,13-20$ & \\
\hline Cathedra s. Petri & $1 \mathrm{Pt} 1,1-7^{62}$ & 1 Pt $1,1-7$ & \\
\hline Vigilia Matthiae & Prv $3,13-20$ & Prv 3, 13-20 & \\
\hline Matthiae & Act $1,15-26^{63}$ & Act $1,15-26$ & \\
\hline Gregorii & Sir $50,1-8$ & Sir $50,1-8$ & \\
\hline Benedicti & $\begin{array}{c}\text { Sap 6, 11-21; Sir 24, } \\
\text { 42-25a }\end{array}$ & $\begin{array}{c}\text { Sap 6, 11-21; Sir 24, } \\
\text { 42-25a }\end{array}$ & \\
\hline Annuntiatio Mariae & Is $7,10-15$ & Is $7,10-15$ & \\
\hline Tiburtii et Valeriani & Prv 15, 2-9 & Prv $15,2-9$ & \\
\hline Georgii & Sir $14,22-27$ & $\begin{array}{c}\text { Sir 14, 22-27; Sap 5, } \\
1-5\end{array}$ & \\
\hline Adalberti & Hbr 5, 1-6; Sap 5, 1-5 & $\begin{array}{c}\text { Sir 14, 22-27; Sap 5, } \\
1-5^{64}\end{array}$ & \\
\hline Marci & Ez 1, 10-14 & Ez $1,10-14^{65}$ & \\
\hline
\end{tabular}




\begin{tabular}{|c|c|c|c|}
\hline 1 & 2 & 3 & 4 \\
\hline Vitalis & $\begin{array}{c}\text { Hbr 13, 9-16; Sap 4, 7- } \\
15^{66}\end{array}$ & $\begin{array}{c}\text { Hbr 13, 9-16; Sap 4, 7- } \\
15\end{array}$ & \\
\hline Philippi et Iacobi & Sap $5,1-5$ & Sap 5, 1-5 & \\
\hline Inventio Sancte Crucis & $\begin{array}{c}\text { Gal } 5,10-12.6,12- \\
14^{67}\end{array}$ & Gal 5, 10-12. 6, 12-14 & \\
\hline $\begin{array}{l}\text { Ioannis ante Portam } \\
\text { Latinam }\end{array}$ & Sir $15,1-6$ & Sir $15,1-6$ & \\
\hline Gordiani et Epimachi & $\begin{array}{c}\text { Hbr 10, 32-38a; Sap 5, } \\
16-22^{68}\end{array}$ & $\begin{array}{c}\text { Hbr 10, 32-38a; Sap 5, } \\
\text { 16-22 }\end{array}$ & \\
\hline $\begin{array}{l}\text { Nerei et Achillei et } \\
\text { Pancratii }\end{array}$ & $\begin{array}{c}\text { Prv } 10,28-32.11 \\
3.6 .8-11 \mathrm{a}\end{array}$ & $\begin{array}{c}\text { Prv } 10,28-32.11 \\
\text { 3.6.8-11a }\end{array}$ & \\
\hline Urbani & Iac $1,11^{69}$ & Iac 1,11 & \\
\hline Marcellini et Petri & $\begin{array}{c}\text { Apc 7, 13-17; Sap 5, } \\
16-22\end{array}$ & $\begin{array}{c}\text { Apc 7, 13-17; Sap 10, } \\
17-20\end{array}$ & \\
\hline Primi et Feliciani & - & $\begin{array}{c}\text { 1P 1, 3-7a. 4, 1-2; Sap } \\
5,16-22\end{array}$ & \\
\hline Barnabae & Eph 2, 19-22 ${ }^{70}$ & Eph $2,19-22$ & \\
\hline Basilidis et Naboris & $\begin{array}{c}\text { Sap 3, 1-8; Hbr 11, 33- } \\
39 a\end{array}$ & $\begin{array}{c}\text { Sap 3, 1-8; Hbr 11, 33- } \\
39 a\end{array}$ & \\
\hline Vincentii & $\begin{array}{c}\text { Prv 10, 28-32. 11, } \\
3.6 .8-11 \mathrm{a} \\
\end{array}$ & $\begin{array}{c}\text { Prv 10,28-32. 11, } \\
\text { 3.6.8-11a } \\
\end{array}$ & \\
\hline Marci et Marceliani & $\begin{array}{c}\text { 2Th 1, 3a.4-10a; Prv } \\
15,2-9\end{array}$ & $\begin{array}{c}\text { 2Th 1, 3a.4-10a; Prv } \\
15,2-9\end{array}$ & \\
\hline Gervasii et Protasii & Sap 10, 17-20 & Sap 10, 17-20 & \\
\hline \multicolumn{4}{|l|}{$\begin{array}{l}\text { Vigilia Nativitatis } \\
\text { Ioannis }\end{array}$} \\
\hline Baptiste & Ier $1,5-10^{71}$ & Ier $1,5-10$ & \\
\hline $\begin{array}{l}\text { Nativitas Ioannis Bap- } \\
\text { tiste }\end{array}$ & Is $49,1-7^{72}$ & Is $49,1-7$ & \\
\hline Ioannis et Pauli & Sir $44,10-15$ & Sir 44, 10-15 & \\
\hline Vigilia Petri et Pauli & Act $3,1-10^{73}$ & Act $3,1-10$ & \\
\hline Petri et Pauli & Act $12,1-11^{74}$ & Act $12,1-11$ & \\
\hline $\begin{array}{l}\text { Commemoratio s. } \\
\text { Pauli }\end{array}$ & Gal $1,11-24^{75}$ & Gal 1, 11-24 & \\
\hline $\begin{array}{l}\text { Octava Ioannis Bap- } \\
\text { tiste }\end{array}$ & Is $49,1-7^{76}$ & Is $49,1-7$ & \\
\hline $\begin{array}{l}\text { Vigilia Visitationis } \\
\text { Mariae }\end{array}$ & Apc $12,1-5^{77}$ & - & \\
\hline Visitatio Mariae & $\mathrm{Ct} 2,8 \mathrm{~b}-14^{78}$ & - & \\
\hline Processi et Martiniani & $\begin{array}{l}\text { Sap 5, 1-5; Prv 10, 28- } \\
32.11,3.6 .8-11 \mathrm{a}\end{array}$ & $\begin{array}{l}\text { Sap 5, 1-5; Prv 10, 28- } \\
32.11,3.6 .8-11 \mathrm{a}\end{array}$ & \\
\hline Udalrici & Sir 47, 9-12a.13a. 24, & Sir 47, 9-12a.13a. 24, & \\
\hline Octava Petri et Pauli & Sir $44,10-15$ & Sir $44,10-15$ & \\
\hline Kiliani & Hbr 11, 33-39a & Hbr 11, 33-39a & \\
\hline $\begin{array}{l}\text { Septem Fratrum mar- } \\
\text { tyrum }\end{array}$ & $\operatorname{Prv} 31,10-31^{79}$ & Prv $31,10-31$ & \\
\hline Translatio s. Benedicti & Sap 6, 11-21 & Sap 6, 11-21 & \\
\hline
\end{tabular}




\begin{tabular}{|c|c|c|c|}
\hline 1 & 2 & $\mathbf{3}$ & 4 \\
\hline Margarite & Sir 51, 1-12 & (de virgine qui placet) & \\
\hline Divisio Apostolorum & Eph 2, 19-22 & Eph $2,19-22$ & \\
\hline Alexii & Sir 47, 9-12a.13a. 24, & Sir 47, 9-12a.13a. 24, & \\
\hline Prasedis & $2 \operatorname{Tim} 4,17-18$ & $2 \operatorname{Tim} 4,17-18$ & \\
\hline Mariae Magdalenae & $\begin{array}{c}\text { Ct 3, 1-4; Lam 3, 24- } \\
25.31-32.56 . \text { Bar 2, } \\
12-14.3,2^{80}\end{array}$ & $\begin{array}{l}\text { Prv 31, 10-31; Sir 24, } \\
1-5.21 \mathrm{~b}-22 \text { (vel qui }\end{array}$ & \\
\hline $\begin{array}{l}\text { placet ex hiis duabus } \\
\text { sequentibus: Ct 3, 1-4; }\end{array}$ & & & \\
\hline $\begin{array}{l}\text { Lam 3, 24-25.31- } \\
\text { 32.56. Bar 2, 12-14. 3, } \\
\text { 2) }\end{array}$ & & & \\
\hline Apollinaris & Sap 10, 10-14 & Sap 10, 10-14 & \\
\hline Vigilia Iacobi & Prv $3,13-20$ & - & \\
\hline Iacobi & Eph 1,3-8a & Eph 1, 3-8a & \\
\hline $\begin{array}{l}\text { Felicis et Simplicii et } \\
\text { Faustini }\end{array}$ & $\begin{array}{c}\text { Sir 2, 18-21; Hbr 7, } \\
23-27\end{array}$ & $\begin{array}{c}\text { Sir } 2,18-21 ; \text { Hbr } 7 \\
23-27\end{array}$ & \\
\hline Abdon et Sennen & $\begin{array}{c}\text { Hbr } 10,32-38 \mathrm{a} ; 2 \mathrm{Th} 1, \\
3 \mathrm{a} .4-10 \mathrm{a}\end{array}$ & $\begin{array}{c}\text { Hbr 10, 32-38a; } 2 \text { Th } 1 \\
3 \mathrm{a} .4-10 \mathrm{a}\end{array}$ & \\
\hline Petri ad Vincula & Act $12,1-11$ & Act $12,1-11$ & \\
\hline Stephani & Sap 4, 7-15 & Sap 4, 7-15 & \\
\hline $\begin{array}{l}\text { Sixti et Felicissimi et } \\
\text { Agapiti }\end{array}$ & $\begin{array}{c}\text { Prv 10, 28-32. 11, } \\
3.6 .8-11 \mathrm{a}\end{array}$ & $\begin{array}{c}\text { Prv 10, 28-32. 11, } \\
3.6 .8-11 \mathrm{a}\end{array}$ & \\
\hline Transfiguratio Domini & $2 \mathrm{Pt} 1,13-19^{81}$ & - & \\
\hline Cyriaci & $\begin{array}{c}\text { Sir 2, 7-13a; } 1 \text { Cor } 4, \\
9 b-14\end{array}$ & $\begin{array}{c}\text { Sir 2, 7-13a; } 1 \text { Cor } 4, \\
9 b-14\end{array}$ & \\
\hline Vigilia Laurentii & Sir 51, 1-8.12 & Sir 51, 1-8.12 & \\
\hline Laurentii & 2 Cor $9,6-10$ & 2 Cor $9,6-10$ & \\
\hline Tiburtii & $\begin{array}{c}\text { Is } 43,1-5 \mathrm{a} ; \operatorname{Sir} 39,6- \\
13\end{array}$ & $\begin{array}{c}\text { Is } 43,1-5 \mathrm{a} ; \text { Sir } 39,6- \\
13\end{array}$ & \\
\hline Hippolyti & $\begin{array}{c}\text { Hbr 10, 32-38a; Prv } \\
15,2-9\end{array}$ & $\begin{array}{c}\text { Hbr 10, 32-38a; Prv } \\
15,2-9\end{array}$ & \\
\hline $\begin{array}{l}\text { Vigilia Assumptionis } \\
\text { Mariae }\end{array}$ & $\begin{array}{c}\text { Sir 24, 23-31; Sir 24, } \\
\text { 14-16 }\end{array}$ & $\begin{array}{c}\text { Sir 24, 23-31; Sir 24, } \\
14-16\end{array}$ & \\
\hline Assumptio Mariae & Sir $24,11 \mathrm{~b}-20^{82}$ & Sir $24,11 b-20$ & \\
\hline Arnolfi & $\begin{array}{c}\text { Sir } 44,16 \ldots 45,20 \text { lub } \\
50,1-8\end{array}$ & $\begin{array}{c}\text { Sir } 44,16 \ldots 45,20 \text { lub } \\
50,1-8\end{array}$ & \\
\hline Octava Laurentii & Sir $31,8-11$ & Sir 31, 8-11 & \\
\hline Agapiti & Sap 4, 7-15 & Sap 4, 7-15 & \\
\hline Magni & Prv $3,13-20$ & & \\
\hline Vigilia Bartholomaei & $\begin{array}{c}\text { Prv } 10,6 \text { a. Sir } 44 \\
\text { 26b.27b. 45, } 2 \text { b- } \\
\text { 4.6a.7-8a.9 }\end{array}$ & $\begin{array}{c}\text { Prv 10, 6a. Sir 44, } \\
\text { 26b.27b. 45, 2b- } \\
\text { 4.6a.7-8a.9 }\end{array}$ & \\
\hline $\begin{array}{l}\text { Octava Assumptionis } \\
\text { Mariae }\end{array}$ & Sir $24,11 b-20$ & Sir $24,11 b-20$ & \\
\hline Bartholomaei & $\operatorname{Rm} 8,28-39$ & $\begin{array}{l}\mathrm{Rm} 8,28-39 \text { (vel alia } \\
\text { de apostolis) }\end{array}$ & \\
\hline
\end{tabular}




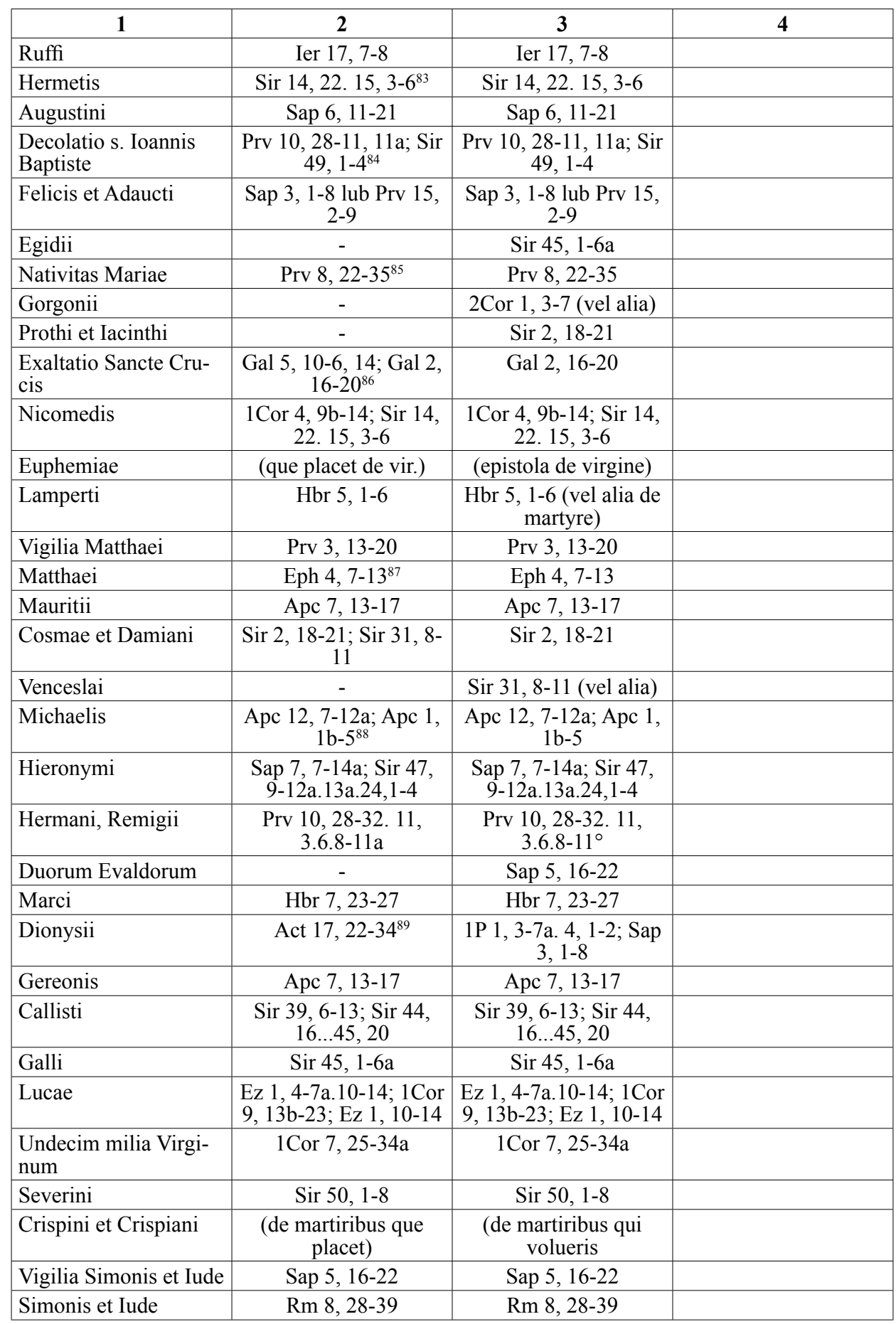




\begin{tabular}{|c|c|c|c|}
\hline 1 & 2 & $\mathbf{3}$ & 4 \\
\hline $\begin{array}{l}\text { Vigilia Omnium Sanc- } \\
\text { torum }\end{array}$ & Apc $5,6-12^{90}$ & Apc 5, 6-12 & \\
\hline Omnium Sanctorum & Apc 7, 2-12 91 & Apc 7, 2-12 & \\
\hline Eustachii & 1 Cor $4,9 b-14$ & 1 Cor $4,9 b-14$ & \\
\hline Leonardi & $\begin{array}{c}\text { Sir 47, 9-12a.13a. 24, } \\
1-4\end{array}$ & $\begin{array}{c}\text { Sir 47, 9-12a.13a. 24, } \\
1-4\end{array}$ & \\
\hline Quatuor Coronatorum & $\begin{array}{c}\text { Hbr 10, 32-38a; Hbr } \\
11,33-39 a\end{array}$ & $\begin{array}{c}\text { Hbr 10,32-38a; Hbr } \\
11,33-39 a\end{array}$ & \\
\hline Theodori & $\begin{array}{c}\text { Sir 39, 6-13; Sap 10, } \\
\text { 10-14 }\end{array}$ & $\begin{array}{c}\text { Sir 39, 6-13; Sap 10, } \\
\text { 10-14 }\end{array}$ & \\
\hline Martini & Sir $50,1-8$ & Sir $50,1-8$ & \\
\hline Bricci & Sir $50,1-8^{92}$ & Sir $44,16 \ldots 45,20$ & \\
\hline Ioannis Elemosinarii & Prv $14,21-23.31^{93}$ & - & \\
\hline Caeciliae & $\begin{array}{c}\text { Sir 24, 1-5.21b-22 lub } \\
\text { Sap 7, 30b-8, 4a }\end{array}$ & $\begin{array}{l}\text { Sir 24, 1-5.21b-22 lub } \\
\text { Sap 7, 30b-8, 4a (vel }\end{array}$ & alia de virgine) \\
\hline Clementis & Phil $3,17-4,3^{94}$ & Phil 3, 17-4, 3 & \\
\hline Chrysogoni & $\begin{array}{l}2 \operatorname{Tim} 2,8-10.3,10- \\
12 ; \operatorname{Sir} 14,22.15,3-6\end{array}$ & $\begin{array}{l}2 \operatorname{Tim} 2,8-10.3,10- \\
\text { 12; Sir 14, 22. 15, 3-6 }\end{array}$ & \\
\hline Catherinae & Sir $51,1-12$ & $\begin{array}{c}\text { Sir 51, 1-12 (vel alia } \\
\text { de virgne) }\end{array}$ & \\
\hline Vigilia Andreae & $\begin{array}{l}\text { Prv 10, 6a. Sir 44, } \\
\text { 26b.27b. 45, 2b- } \\
\text { 4.6a.7-8a.9 }\end{array}$ & $\begin{array}{c}\text { Prv 10, 6a. Sir 44, } \\
\text { 26b.27b. 45, 2b- } \\
\text { 4.6a.7-8a.9 }\end{array}$ & \\
\hline Andreae & $\mathrm{Rm} 10,10-18$ & $\mathrm{Rm} 10,10-18$ & \\
\hline Nicolai & Sir $50,1-8$ & $\begin{array}{l}\text { Sir 14, 22-27 (vel } \\
\text { aliam lege) }\end{array}$ & \\
\hline $\begin{array}{l}\text { Dominica - de Sancta } \\
\text { Trinitate }\end{array}$ & 2 Cor $13,11-13^{95}$ & $\begin{array}{c}\text { Rm 11,33-36; 2Cor } \\
13,11-13\end{array}$ & \\
\hline feria II - de sapientia & Sap 9, 1-5a & Sap 9,1-5a & Sap 9, 1-5a \\
\hline $\begin{array}{l}\text { feria III - de Sancto } \\
\text { Spiritu }\end{array}$ & 1 Cor $12,7-11^{96}$ & 1 Cor $12,7-11$ & 1 Cor $12,7-11$ \\
\hline feria IV - de angelis & Apc 19,9-10a & Apc 19,9-10a & Apc 19,9-10a \\
\hline feria $\mathrm{V}$ - de caritate & 1 Cor $13,1-8 a^{97}$ & 1 Cor $13,1-8 \mathrm{a}$ & 1 Cor $13,1-8 \mathrm{a}$ \\
\hline $\begin{array}{l}\text { feria VI - de Sancta } \\
\text { Cruce }\end{array}$ & Phil 2, 8-11 & Phil 2, 8-11 & Phil 2, 8-11 \\
\hline \multicolumn{4}{|l|}{ sabbato } \\
\hline \multirow[t]{2}{*}{$\begin{array}{l}\text { - de Domina[per an- } \\
\text { num] }\end{array}$} & $\begin{array}{c}\text { Prv 31, 25-2998; Sir 24, } \\
\text { 11b-16; }\end{array}$ & Sir $24,23-31^{99}$ & $\begin{array}{l}\text { Prv 31, 10-31 }{ }^{100} ; \text { Sir } \\
\text { 24, 11b-16; }\end{array}$ \\
\hline & $\begin{array}{c}\text { Sap 7, 30b-8, 4a; Sir } \\
24,23-31^{101}\end{array}$ & Sir $24,14-16$ & $\begin{array}{c}\text { Sap 7, 30b-8, 4a; Sir } \\
24,23-31 ;\end{array}$ \\
\hline $\begin{array}{l}\text { - [de Domina]Tempore } \\
\text { paschali Act 1, 12-14; } \\
\text { Sir 24, 14-16 }\end{array}$ & Act $1,12-14^{102}$ & $\begin{array}{l}\text { Sir 24, 14-16; in Ad- } \\
\text { ventu Is } 7,10-15\end{array}$ & \\
\hline Dedicatio ecclesiae & $\begin{array}{c}\text { Apc 21, 2-5a; 1Cor 3, } \\
8 \mathrm{~b}-15 ;\end{array}$ & $\begin{array}{c}\text { Apc 21, 2-5a; 1Cor 3, } \\
8 \mathrm{~b}-15\end{array}$ & \\
\hline $\begin{array}{l}\text { Is } 18,7 \mathrm{a} .19 \\
\text { 4b.19.21.22b.24-25 }\end{array}$ & $\begin{array}{c}\text { Is 18, 7a. 19, } \\
\text { 4b.19.21.22b.24-25 }\end{array}$ & & \\
\hline
\end{tabular}




\begin{tabular}{|c|c|c|c|}
\hline 1 & 2 & 3 & 4 \\
\hline Vigilia unius Apostoli & Prv 3, 13-20; & Prv 3, 13-20; & \\
\hline $\begin{array}{l}\text { Prv 10,6a. Sir 44, } \\
\text { 26b.27b. 45, 2b- } \\
\text { 4.6a.7-8a.9 }\end{array}$ & $\begin{array}{c}\text { Prv 10, 6a. Sir 44, } \\
\text { 26b.27b. } 45,2 \text { b- } \\
\text { 4.6a.7-8a.9 }\end{array}$ & & \\
\hline Apostolorum & $\begin{array}{l}\text { Eph 2, 19-22; Eph 1, } \\
\text { 3-8a; Rm 8, 28-39; }\end{array}$ & $\begin{array}{l}\text { Eph 2, 19-22; Eph 1, } \\
\text { 3-8a; Rm 8, 28-39; }\end{array}$ & \\
\hline $\begin{array}{l}\text { Rm 10, 10-18; Act 5, } \\
17-21 \mathrm{a} ; \text { Act } 5,12- \\
16^{104}\end{array}$ & $\begin{array}{l}\text { Rm 10, 10-18; Act 5, } \\
\text { 17- 21a; Act 5, 12-16 }\end{array}$ & & \\
\hline Evangelistarum & $\begin{array}{c}\text { Ez 1, 4-7a.10-14; Apc } \\
\text { 4, 1-10a; }\end{array}$ & $\begin{array}{c}\text { Ez 1, 4-7a.10-14; Apc } \\
\text { 4, 1-10a; }\end{array}$ & \\
\hline $\begin{array}{l}\text { Eph 4, 7-13; } 1 \text { Cor 9, } \\
13 b-23^{105}\end{array}$ & $\begin{array}{c}\text { Eph 4, 7-13; 1Cor } 9, \\
13 \mathrm{~b}-23\end{array}$ & & \\
\hline Martyrum & $\begin{array}{c}\text { Sap 3, 1-8; Sap 5, 16- } \\
\text { 22; }\end{array}$ & $\begin{array}{c}\text { Sap 3, 1-8; Sap 5, 16- } \\
22 ;\end{array}$ & \\
\hline $\begin{array}{l}\text { Prv 10, 28-32. 11, } \\
\text { 3.6.8-11a; Sap 10, } 17- \\
20 ;\end{array}$ & $\begin{array}{c}\text { Prv 10, 28-32. 11, } \\
\text { 3.6.8-11a; Sap 10, 17- } \\
\text { 20; }\end{array}$ & & \\
\hline $\begin{array}{l}\text { Sir 2, 18-21; Sap 5, 1- } \\
\text { 5;Sir 44, 10-15; }\end{array}$ & $\begin{array}{l}\text { Sir 2, 18-21; Sap 5, 1- } \\
\text { 5;Sir 44, 10-15; }\end{array}$ & & \\
\hline $\begin{array}{l}\text { Prv 15, 2-9; Apc 7, 13- } \\
\text { 17; Sir 2, 7-13a; }\end{array}$ & 1Cor 4, 9b-14; & $\begin{array}{l}\text { Prv 15, 2-9; Apc 7, } \\
13^{106} ; 1 \mathrm{Pt} 4,1-2^{107} ;\end{array}$ & \\
\hline $\begin{array}{l}\text { 1Pt 1, 3-7a. 4, 1-2; } \\
\text { 2Th 1, 3a.4-10a; }\end{array}$ & Hbr 11, 33-39a; & $\begin{array}{l}\text { 2Th 1, 3a.4-10a; } 2 \text { Cor } \\
1,3-7^{108}\end{array}$ & \\
\hline $\begin{array}{l}\text { 2Cor } 1,3-7 ; 1 \text { Cor } 4, \\
9 b-14 ; \text { Hbr } 11,33-39 a ;\end{array}$ & $2 \operatorname{Tim} 2,4-10$ & & \\
\hline $\begin{array}{l}2 \operatorname{Tim} 2,4-10 ; \text { Hbr } 10, \\
32-38 \mathrm{a}\end{array}$ & Hbr 10, 32-38a & & \\
\hline Unius martyris & $\begin{array}{l}\text { Sir 14, 22. 15, 3-6; Sir } \\
\text { 31, 8-11; Ier 17, 7-8; }\end{array}$ & & \\
\hline \multicolumn{4}{|l|}{$\begin{array}{l}\text { Sap 10, 10-14; Sir 39, } \\
\text { 6-13; Sap 4, 7-15; }\end{array}$} \\
\hline \multicolumn{4}{|l|}{$\begin{array}{l}\text { Sir } 51,1-8.12 ; 2 \text { Cor } 9 \\
6-10 ; 2 \text { Tim } 4,17-18\end{array}$} \\
\hline \multicolumn{4}{|l|}{$\begin{array}{l}2 \operatorname{Tim} 4,1-8 ; 2 \operatorname{Tim} 2 \\
8-10.3,10-12\end{array}$} \\
\hline \multicolumn{4}{|l|}{ Is $43,1-5 \mathrm{a}^{109}$} \\
\hline Unius confessoris & $\begin{array}{l}\text { Sir 44, 16...45, 20; Sir } \\
\text { 50, 1-8; Sir 45, 1-6a; }\end{array}$ & $\begin{array}{l}\text { Sir 44, 16...45, 20; Sir } \\
\text { 50, 1-8; Sir 45, 1-6a; }\end{array}$ & \\
\hline $\begin{array}{l}\text { Sir 47, 9-12a.13a. 24, } \\
\text { 1-4; Sir 24, 42-25, 2a; }\end{array}$ & $\begin{array}{l}\text { Sir 47, 9-12a.13a. 24, } \\
\text { 1-4; Sir 24, 42-25, 2a; }\end{array}$ & & \\
\hline $\begin{array}{l}\text { Sir 39, 1-5; Sap 6, 11- } \\
\text { 21; Sap 7, 7-14a; }\end{array}$ & $\begin{array}{l}\text { Sir 39, 1-5; Sap 6, 11- } \\
\text { 21; Sap 7, 7-14a; }\end{array}$ & & \\
\hline $\begin{array}{l}\text { Sir 14, 22-27; Mal 2, } \\
\text { 4-7; Hbr 7, 23-27; }\end{array}$ & $\begin{array}{l}\text { Sir 14, 22-27; Mal 2, } \\
\text { 4-7; Hbr 7, 23-27; }\end{array}$ & & \\
\hline $\begin{array}{l}\text { Hbr 5, 1-6 }{ }^{110} ; \text { Hbr 13, } \\
9-16\end{array}$ & $\begin{array}{c}\text { Hbr 5, 1-6; Hbr 13, 9- } \\
16\end{array}$ & & \\
\hline Virginum & $\begin{array}{c}\text { Sir 51, 1-12; Sir 51, } \\
\text { 13-17a; }\end{array}$ & $\begin{array}{c}\text { Sir 51, 1-12; Sir 51, } \\
13-17 \mathrm{a} ;\end{array}$ & \\
\hline
\end{tabular}




\begin{tabular}{|c|c|c|c|}
\hline 1 & 2 & 3 & 4 \\
\hline $\begin{array}{l}\text { Sap 7, 30b-8, 4a;Sir } \\
24,\end{array}$ & 1-5. 24, 21b-22; & $\begin{array}{c}\text { Sap 7, 30b-8, 4a;Sir } \\
24,\end{array}$ & 1-5. 24, 21b-22; \\
\hline $\begin{array}{l}2 \text { Cor } 10,17-11,2 ; \\
1 \text { Cor } 7,25-34 a^{111}\end{array}$ & $\begin{array}{c}\text { 2Cor 10, 17-11, 2; } \\
\text { 1Cor 7, 25-34a; } 2 \text { Tim } \\
\text { 4, 17-18 }\end{array}$ & & \\
\hline Pro peccatis & $\begin{array}{l}\text { Ier 14, 7-8a.9b; Ier 10, } \\
23-24.14,20-21 \mathrm{a} ;\end{array}$ & 1Io 1,7b-9; 1Io 2, 1-2 & \\
\hline \multicolumn{4}{|l|}{$\begin{array}{l}\text { 1Esr 9, 6-7a. 2Esr 1, } \\
\text { 11. 9, 17b(32); }\end{array}$} \\
\hline \multicolumn{4}{|l|}{$\begin{array}{l}\text { 1Io 1,5b-9; 1Io 2, 1- } \\
2^{112}\end{array}$} \\
\hline $\begin{array}{l}\text { In anniversario conse- } \\
\text { crationis }{ }^{113} 1 \text { Tim } 3,1- \\
7 \mathrm{a} ; 2 \text { Tim } 3,16-4,2 \text {; } \\
\text { Mt } 10,5^{114} ;\end{array}$ & $\begin{array}{l}1 \operatorname{Tim} 3,1-7 \mathrm{a} ; 2 \operatorname{Tim} 3, \\
\text { 16-4, 2; Mt 10, 5; }\end{array}$ & & \\
\hline Lc $12,42-44^{115}$ & Lc $12,42-44$ & & \\
\hline Pro pluvia & Ier $14,19-22$ & Ier $14,19-22$ & \\
\hline Pro serenitate & Lam 2, 19-20. 3, 47-58 & Lam 2, 19-20. 3, 47-58 & \\
\hline Defunctorum & $\begin{array}{c}2 \mathrm{Mcc} 12,43-46 ; \text { Is } 58, \\
10 \mathrm{~b}-11 ;\end{array}$ & $\begin{array}{c}2 \mathrm{Mcc} 12,43-46 ; \text { Is } 58 \\
10 \mathrm{~b}-11\end{array}$ & \\
\hline $\begin{array}{l}\text { 1Th 4, 13-18; Apc 14, } \\
\text { 13; Ez 37, 1-6; }\end{array}$ & $\begin{array}{c}\text { 1Th 4, 13-18; Apc 14, } \\
\text { 13; Ez 37, 1-6; }\end{array}$ & & \\
\hline $\begin{array}{l}\text { 1Cor } 15,51-57 \text {; } 1 \text { Cor } \\
15,20-23 \mathrm{a}\end{array}$ & $\begin{array}{c}1 \text { Cor } 15,51-57 \text {; } 1 \text { Cor } \\
15,20-23 \mathrm{a}\end{array}$ & & \\
\hline
\end{tabular}

\section{Przypisy do tabeli}

${ }^{1} \mathrm{~W}$ środek wiersza 50 wstawiono wiersze 47-48. Po 51 następuje hymn trzech młodzieńców „Benedictus”. Uwagi dotyczące zawartości poszczególnych perykop zachowują ważność w odniesieniu do ich każdorazowego pojawienia się.

${ }^{2}$ Mszały z 1515 r. (k. IXr) i z 1532 r. (k. 9r) podają również lekcję na „feria sexta”: ma to być czytanie z niedzieli lub (tylko według 1515 r.) $2 \mathrm{Th} 3,13-16$.

3 „In alia feria”.

${ }^{4}$ Na dołączonej karcie 47rv z tytułem ,feria IV post Dominicam Memento".

${ }^{5}$ Wiersz 10 tylko w części b.

${ }^{6}$ Bez wiersza 15, 2 b.

${ }^{7}$ Mszał z 1532 r. (18r) ma tylko lekcję z Listu do Rzymian.

${ }^{8}$ Od słów: ,et reges in splendore ortus tui”, rozpoczyna się fragment czytania, k. $1 \mathrm{r}$.

${ }^{9}$ Mszał z 1532 r. nie zawiera lekcji (ani formularzy mszalnych) na kolejne wszystkie środy aż do początku Wielkiego Postu.

${ }^{10}$ „Require hic ante in vigilia epyphanie”.

${ }^{11}$ Ostatnim zapisanym na stronie słowom: „det vobis pacem”, brakuje zakończenia, k. 1v.

${ }^{12}$ Pierwsze zapisane słowa tego czytania: ,[preveni]entes. Sollicitudine non pigri”, wyraźnie oderwane są od początku tekstu, k. 2 r.

${ }^{13}$ Bez wiersza 5, $19 \mathrm{~b}$.

${ }^{14}$ Zaznaczono: „vacans, si est necessaria”.

${ }^{15} \mathrm{Na}$ marginesie naniesiono uwagę: „Si fuit necesse”. 
${ }^{16}$ Pomiędzy końcowe słowa wiersza 20, 6 wstawiono glosę: „clamaveruntque ad Dominum atque dixerunt, Domine Deus exaudi clamorem populi huius et aperi eis tesaurum tuum fontem aque vive ut sociati cesset murmuratio eorum".

${ }^{17}$ Lekcja z proroka Izajasza „ad missam”.

${ }^{18}$ Bez wiersza 3, 7b.

${ }^{19}$ Oraz niektóre słowa z wierszy 6, 25 i 6, 26.

${ }^{20}$,super frondes".

${ }^{21}$ „ad missam”.

22 "super frondes".

${ }^{23}$ "ad missam”.

${ }^{24}$ Bez wiersza 63, 6.

${ }^{25}$ „ad missam”.

${ }^{26}$ Zaznaczono tractus „Domine audivi”.

${ }^{27}$ Zaznaczono tractus „Domine audivi”.

${ }^{28}$ W tym miejscu zapisano: ,tractus Vinea facta”.

${ }^{29}$ Zaznaczono tractus „Cantemus”.

${ }^{30}$ Zaznaczono tractus „Vinea”.

${ }^{31}$ Lekcja z Listu do Kolosan ,ad missam”

${ }^{32}$ Bez wiersza 3, 16.

${ }^{33}$ W tym miejscu zapisano: „Vel hanc Omnes gentes plau[dite]”. Zapewne przez pomyłkę, gdyż jest to incipit introitu na środę Dni Krzyżowych lub wersetu po czytaniu na ten dzień.

${ }^{34}$ Prawdopodobnie powinno być ,feria IV Rogationibus", tak jak mają mszały z 1515 r. i z 1532 r., które nie mają z kolei lekcji In Vigilia Asc. Eph 4, 7-13.

${ }^{35}$ Mszały z 1515 r. i z 1532 r. mają na ten dzień tylko: „omnia ut hieri” lub „ut ipso die fiunt”.

${ }^{36}$ „vel infra totam octavam".

${ }^{37}$ Mszały z 1515 r. i z 1532 r. stosują określenie ,feria sexta post octavam ascensionis” (k. CXXv, k. 119v), zaś mszał z 1515 r. ma nadto lekcję na „feria quarta”: Eph 4, 7-13, k. CXXr.

${ }^{38}$ Lekcja z Dziejów Apostolskich „ad missam”.

${ }^{39}$ Wstawiony zwrot „Viri fratres et patres” $\mathrm{z}$ wiersza 7, 2

${ }^{40}$ Bez wiersza 8, 7b.

${ }^{41}$ Zob. przypis w środę suchych dni adwentowych.

${ }^{42}$ Mszał z 1532 r. nie ma tego obchodu.

${ }^{43}$ Poniżej samego incipitu lekcji zapisano: „Affectuose moneo ut quicumque in hoc libello ad divinum officium legitur, Pater noster et orationem: Deus cui populus est misertus pro anima scriptoris intuitu divine pietatis decantare velit (in fine libri require)".

${ }^{44}$ Jak w Wielki Czwartek: „Queratur in Cena Domini”.

${ }^{45} \mathrm{Na}$ marginesach wielkoczwartkowej lekcji (k. 50) dopisano: „Divisio de Corpore Christi Ego enim” i krzyżykiem zaznaczono początkowe miejsce perykopy oraz „hic finis huius divisio et non in diiudicans”, również znacząc krzyżykiem końcowe miejsce „manducat et bibit”, podkreślając zarazem, że nie na słowie diiudicans należy zakończyć lekcję.

${ }^{46}$ Mszał z 1532 r. nie ma formularzy mszalnych i lekcji na wszystkie środy okresu ,post Trinitatis" z wyjątkiem środy po 17 niedzieli, kiedy przypadały jesienne Dni Kwartalne.

${ }^{47}$ Bez wiersza 4, 9a.

${ }^{48}$ Bez wiersza 15, 4.

${ }^{49}$ Podano tylko incipit oraz instrukcję: „,Require post octavam Epiphanie in feria VI ante Circumdederunt me proxima”.

${ }^{50}$ „Require post octavam Epiphanie in sexta feria ante Circumdederunt me”. Tu zaznaczono słowa lekcji 3, 1b-2a.

${ }^{51}$ Bez wierszy 7, 15. 16b-17. 
${ }^{52}$ Zob. przypis w środę suchych dni adwentowych.

${ }^{53}$ „Require in adventu Domini”.

${ }^{54}$ Podano tekst Phil 3, 17-21, ale na marginesie widnieje zapis: „Finem istius epistole habes infra in die s. Clementis post festum Sanctorum Omnium" (94r). Jednak mszały z 1515 r. i 1532 r. poprzestają tylko na tym fragmencie.

${ }^{55}$ Jeżeli nie zaznaczono inaczej, poniższe lekcje na obchody świętych - zgodnie z rubrykami umieszczonymi tak w Lectionarium jak w Epistolare - zaczerpnięte są z tekstów wspólnych.

${ }^{56}$ Dopisano na marginesie.

${ }^{57}$ Lekcja ułożona $z$ wybranych pojedynczych wierszy, a nawet tylko poszczególnych zwrotów. Mszały z 1515 r. (k. XVIIv) i z 1532 r. (17r) podają Sir 50, 1-8.

${ }^{58} \mathrm{~W}$ tym miejscu dopisano na marginesie ,et Isaie”, k. 23v. Obydwa obchody - Thomae i Silvestri - umieszczono w części de tempore tego lekcjonarza.

${ }^{59}$ Bez wiersza 51, 6 a.

${ }^{60}$ Lekcja własna; między wersetami 9, 5 a 9, 7 (przy brakującym 9, 6) wstawiono glosę: „Durum est tibi contra stimulum calcitare (Dz 26, 14b) et ille tremens ac stupeas dixit: Domine quod me vis facere, et Dominus ad illum".

${ }^{61}$ Lekcja własna.

${ }^{62}$ Lekcja własna.

${ }^{63}$ Lekcja własna.

${ }^{64}$ Obchód św. Jerzego i św. Wojciecha wyznaczono na ten sam dzień.

${ }^{65} \mathrm{Na}$ marginesie drobnymi literami zaznaczono: „Require in epistola Vidi et ecce de evangelistis", k. $117 \mathrm{r}$.

${ }^{66}$ Bez wierszy 4, 12 i 14b.

${ }^{67}$ Lekcja własna.

${ }^{68}$ Bez wiersza 5, 21.

${ }^{69}$ Tej lekcji nie ma w „Epistole sanctorum communes”.

${ }^{70}$ Mszał z 1515 r. zaznacza, że w innych kościołach, to znaczy poza katedrą, odczytuje się lekcję z Act 13, 44-52, k. CCXv.

${ }^{71}$ Lekcja własna.

${ }^{72}$ Lekcja własna; bez wierszy 49, 4. 5b-6a. 7a.

${ }^{73}$ Lekcja własna.

${ }^{74}$ Lekcja własna.

${ }^{75}$ Lekcja własna.

${ }^{76}$ Lekcja własna; bez wierszy 49, 4. 5b-6a. 7a.

${ }^{77}$ Lekcja własna.

${ }^{78}$ Lekcja własna.

${ }^{79}$ Lekcja własna.

${ }^{80}$ Lekcje własne; bez wiersza Bar 2, 13 b.

${ }^{81}$ Lekcja własna.

${ }^{82}$ Lekcja własna; bez wiersza 24, 14.

${ }^{83}$ Bez wierszy 15, 5-6a.

${ }^{84}$ Lekcja własna. W mszale z 1532 r. tekst tej lekcji jest wydłużony przez dodanie wierszy: 49, 9. 50, 6-7.

${ }^{85}$ Lekcja własna.

${ }^{86}$ Lekcja własna.

${ }^{87}$,vel que placet de evangeliste”.

${ }^{88}$ Lekcje własne; w lekcji z Apokalipsy zwrot „Ioannes septem ecclesiis que sunt in asia” zapisano dwukrotnie. 
89 „Stans Paulus in ut in fine libri”, ale tej lekcji nie ma w „Epistole sanctorum communes”. Według mszałów drukowanych to fragment Dziejów Apostolskich 17, 22-34.

${ }^{90}$ Lekcja własna.

${ }^{91}$ Lekcja własna.

${ }^{92}$ „eadem epistole leguntur”.

${ }^{93}$ Lekcja własna.

${ }^{94}$ Lekcja własna; podano tekst Phil 4, 1-3, a na marginesie widnieje zapis: „Initium istius epistole vide super Dominica 23 post Pent. Imitatores mei estote et" (109r). Jednak i tym razem mszały z 1515 r. i 1532 r. również poprzestają na podanym tu fragmencie.

${ }^{95}$ Bez wiersza 13, 12.

${ }^{96}$ „Require in Dominica X post pentecostes in media epistola: Scitis quam cum gentes estis”, $\mathrm{k}$. $109 \mathrm{v}$.

${ }^{97}$ Mszały z 1515 r. i 1532 r. mają lekcję krótszą: 1Cor 13, 4-8a.

98 „Require VII fratrum et lege usque Tu supergressa est”.

${ }^{99}$ Ten lekcjonarz nie rozróżnia pomiędzy tekstami „,per annum” i „tempore paschali”, podaje natomiast taką informację: „sabbato vel quando agitur de Domina”, k. 37v.

100 „Require in festo VII fratrum”.

${ }^{101}$ Mszał z 1515 r. nie ma lekcji: Prv 31, 25; Sir 24, 11b; Sap 7, 30b; posiada natomiast dodatkowo Sir 24, 14, której nie ma in tempore paschali, zaś in tempore ascensioni ma Act 1, 12. Mszał z 1532 r. ma tylko w mszy de Domina per annum Sir 24, 14; in tempore paschali Sir 24, 23; in tempore ascensioni Act 1, 12.

${ }^{102}$ Od połowy wiersza 1,13 uzupełnienie na dołączonej karcie 47.

${ }^{103}$ Mszały z 1515 r. i 1532 r. mają tylko lekcję z 1Cor 3, natomiast z Is 18 przeznaczają ,in consecratione altaris", a dodatkowo na ten obchód podają Apc 8, 1-5 (CLXXIIr, 163r).

${ }^{104}$ Mszał z 1532 r. nie ma lekcji Rm 10, 10 i Act 5, 17.

${ }^{105}$ Mszał z 1532 r. nie ma lekcji 1Cor 9, 13b.

${ }^{106}$ k. $141 \mathrm{v}$ - tekst urywa się, brakuje właściwej karty.

${ }^{107}$ k. 142 r - tekst rozpoczyna się końcówką przewidzianej lekcji.

${ }^{108} \mathrm{k} .142 \mathrm{v}$ - tekst nieznacznie naderwany w końcówce.

${ }^{109}$ Mszał z 1515 r. nie ma lekcji Sir 51, 1; a z 1532 r. 2Cor 9, 6, ale ma dodatkowo Hbr 5, 1.

${ }^{110}$ Tej lekcji nie ma w mszale z $1532 \mathrm{r}$.

${ }^{111}$ Mszał z 1515 r. ma dodatkowo 2Tim 4, 17-18; obydwa mszały podają nadto lekcję w mszy „de vidua sive electa”, Prv 31, 10-31.

${ }^{112}$ Mszały mają tylko lekcję Ier 14, 7.

${ }^{113}$ Czytania sugerują, że chodzi o rocznicę święceń biskupich. Mszały nie posiadają rubryki dla takiego obchodu.

${ }^{114}$ Ewangelia wg św. Mateusza (podano tylko incipit).

${ }^{115}$ Ewangelia wg św. Łukasza.10) P. Szymon Fedorowicz 


\section{MITTELALTERLICHE LEKTIONARE IN DEN SAMMLUNGEN DER WAWELBURG}

\section{Zusammenfassung}

In den Beständen des Archivs und der Bibliothek des Krakauer Domkapitels werden drei mittelalterliche Lektionare aufbewahrt, die die lateinischen Texte der Lesungen enthielten, die zur Rezitation oder zum Singen während der Messliturgie vorgesehen waren. Und obwohl sie einander im Inhalt naturgemäß sehr ähneln, unterscheiden sie sich dennoch durch individuelle Züge, die in Bezug auf die schließlich unverwechselbaren Handschriftencodizes verständlich sind. Die Charakteristik und die Verschiedenheiten aller drei Bücher stellen wir getrennt vor, während ihr sachlicher Inhalt in einer allgemeinen Zusammenstellung abgehandelt wird.

Die Manuskripte entstanden durch Benutzung eines bestimmten Schreibmaterials, man bediente sich der damaligen Buchbindetechnik, befolgte die geltenden redaktionellen und handwerklichen Prinzipien und führte künstlerische Elemente hinzu. Alle hier genannten Stufen der Codexherstellung zeigen - nach einer detaillierten Analyse - trotz des sachlich gleichen Inhalts die Unverwechselbarkeit jedes einzelnen Exemplars, seine Spezifik und Originalität.

Jedes der hier besprochenen Lektionare entstand zu einem völlig anderen Zeitpunkt: eines im 12. Jahrhundert, das zweite im 14. Jahrhundert und das dritte im Jahre 1500. Aber wahrscheinlich wurden alle drei am selben Ort hergestellt, und zwar in Krakau. Darauf verweisen zahlreiche kleinere Ähnlichkeiten redaktioneller Natur, auch wenn dies selbstverständlich keinen vollständigen Beweis darstellt. Beim Betrachten dieser Bücher kann man sich des Eindrucks nicht erwehren, dass die jeweiligen Schreiber die schon früher von ihren Vorgängern angefertigten Werke zur Hand hatten. Manchmal verübten sie dieselben Fehler, notierten in den Rubriken dieselben Bemerkungen in Bezug auf dieselben Texte oder dieselben liturgischen Tage. Vieles besagen auch die Zusammenstellungen der Lesungen, die sich - in den erhaltenen Teilen jedenfalls - fast völlig decken, was gewiss nicht denkbar gewesen wäre, wenn diese Handschriften völlig woanders entstanden wären. Ihre gegenseitige Abhängigkeit scheint außer Zweifel zu stehen, auch wenn sie charakteristische Besonderheiten besitzen, die jeweils von der Epoche geprägt sind, in der sie hergestellt wurden. 